Şırnak Üniversitesi

İlahiyat Fakültesi Dergisi

Cilt: 11, Sayı: 25, Aralık 2020

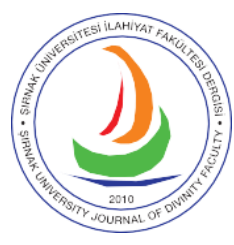

e-ISSN 2667-6575
Şırnak University

Journal of Divinity Faculty

Volume: 11, Issue: 25, December 2020

\title{
Ulûmü'l-Kur'ân ve Tefsir Usûlü Kâideleri Bağlamında Musannifek'in Yazma Tefsir Nüshaları Üzerine Bir İnceleme
}

An Assessment on Manuscripts of Musannifek Tafsir in the Context of U'lûmü'l-Qur'an and Tafsir Methodology

İsa KANIKK

Dr. Öğr. Üyesi, Kırşehir Ahi Evran Üniversitesi, İslami İlimler Fakültesi, Tefsir Ana Bilim Dalı Assistant Professor, Kırşehir Ahi Evran University, Faculty of Islamic Sciences, Department of Tafsir

Kırşehir, Turkey isa.kanik@ahievran.edu.tr https://orcid.org/0000-0003-4338-7834

\section{Makale Bilgisi / Article Information}

Makale Türü / Article Types: Araştırma Makalesi / Research Article

Geliş Tarihi / Received: 23 Eylül / September 2020

Kabul Tarihi / Accepted: 29 Ekim / October 2020

Yayın Tarihi / Published: 15 Aralık / December 2020

Cilt / Volume: 11 Sayı / Issue: 25 Sayfa / Pages: 594-627

Atıf / Cite as: Kanik, İsa. “Ulûmü'l-Kur'ân ve Tefsir Usûlü Kâideleri Bağlamında Musannifek'in Yazma Tefsir Nüshaları Üzerine Bir İnceleme [An Assessment on Manuscripts of Musannifek Tafsir in the Context of Ulûmü'l-Qur'an and Tafsir Methodology]". Şırnak Üniversitesi İlahiyat Fakültesi Dergisi Şırnak University Journal of Divinity Faculty 11/25 (December 2020), 594-627. https://doi.org/10.35415/sirnakifd.799347

Etik Beyanı / Ethics Declaration: Bu makalede bilimsel araştırma ve yayın etiği ilkelerine riayet edilmiştir. Makale etik izin gerektirmeyen bir çalışma olup en az iki hakem tarafından incelenmiş ve intihal içermediği teyit edilmiştir./ In this article, the principles of scientific research and publication ethics are respected. The article is a study that does not require ethical permission. It has been reviewed by at least two referees and was confirmed that it did not contain plagiarism.

Copyright (C Published by Şırnak Üniversitesi, İlahiyat Fakültesi / Şırnak, Türkiye (Şırnak University, Faculty of Divinity, Şırnak, 73000 Turkey). 
Öz

Kur'ân âyetleri indirildiği andan itibaren hıfzedilmiş; deri, tahta, taş ve kemik gibi farklı yazı malzemeleri üzerine kaydedilmiştir. Gerek lafzı gerekse manası bu şekilde korunagelmiştir. Kıraati, tilaveti, cem'i ve istinsahına azamî hassasiyet gösterilen Kur'ân'ın, yazma veya matbu halinde yüzlerce hatta binlerce tefsiri bulunmaktadır. Söz konusu yazma tefsir eserlerinden biri de Osmanlı dönemi müfessirlerinden Alâüddîn Alî b. Muhammed b. Mes'ûd el-Bistâmî eş-Şâhrûdî’ye(Musannifek) (öl. 875/1470) aittir. Bu araştırmada farklı iki nüshasına ulaşabildiğimiz Musannifek tefsirinin metot ve muhtevası ile Kur'ân ilimleri ve tefsir usûlü konusundaki ilkeleri tahlil edilmektedir. Bu tahlil ve değerlendirmelerde sûrelerin mushaf sıralamasına göre tefsir edildiği gözlemlenmektedir. Döneminin tefsir ve tefsir usûlü anlayışını da yansıtan eserde Farsça ağırlıklı olmakla birlikte yer yer detaylı Arapça izahlara yer verilmektedir. Konya Yazma Eser Kütüphanesi'ndeki nüshada Sâd sûresi'nden Nâs'a kadarki sûreler tefsir edilmekte; Beyazıt Kütüphanesi'ndeki nüshada ise Bakara sûresi'nden bazı âyetler tefsir edilerek tefsir usûlü ve Kur'ân ilimleri ile ilgili kâidelere değinilmektedir. Bu çalışmamızla Musannifek tefsirinin şekil, içerik ve diğer hususlar bakımından ele alınarak tefsir ve tefsir usûlü perspektifinden incelenmesi amaçlanmaktadır. Kaydına ulaşabildiğimiz bu nüshalar bağlamındaki tespitlerimiz Musannifek ve tefsirinin tanınmasına da önemli katkı sağlamaktadır.

Anahtar Kelimeler: Tefsir, Kur'ân, Musannifek, Ulûmü'l-Kur'ân, Yazma.

\begin{abstract}
The verses of the Qur'ān have been preserved from the time they were descended; they have been written on different writing materials such as leather, wood, stone, and bone. Both its words and its meaning have been preserved in this way. The recitation, collection, and reproduction of the Qur'ān have been extremely sensitive issues. There are hundreds or even thousands of exegeses of the Qur'ān in handwriting or print. One of the aforementioned manuscript exegesis belongs to Alâüddîn Alî $b$. Muhammed b. Mes'ûd elBistâmî eş-Şâhrûdî (Musannifek) (öl. 875/1470) who was one of the tafsir writers of the Ottoman period. In this study, the method and content of the Musannifek's tafsir, two different copies of which can be accessed and his principles of the Qur'anic discipline and the tafsir method are analyzed. In these analysis and evaluations, it is observed that the surahs are interpreted according to the order of mushaf. The work, which also reflects the tafsir and the understanding of tafsir methodology of the period, includes occasional detailed Arabic explanations, although it is mainly Persian. In the copy at Konya Manuscript Library the chapters from surah Sâd to Nâs are interpreted; In the copy at the Beyazit Library, some verses from the surah al-Baqara are interpreted and the traditions related to the tafsir method and the disciplines of the Qur'an are mentioned. This study aims to examine the interpretation of Musannifek in terms of form, contend and other issues from the perspective of tafsir and tafsir methodology. Our findings in the context of these manuscripts, which could be accessed make a significant contrubition to the recognition of Musannifek and his exegesis.
\end{abstract}

Keywords: Tafsir, Qur’ān, Musannifek, Quranic Sciences, Manuscript. 


\section{Extended Abstract}

The Quran sent to people by Almighty Allah is a great and holy book. The Quran is read repeatedly since its revelation; its words, meanings, language, and literary features are constantly being analyzed. As a result of the great sensitivity shown to the Quran in scientific, theoretical, and practical points, different understandings and interpretations of the Quran have been revealed in parallel with the characteristics of peoples and ages. In this process, various works have been given because of activities carried out sometimes with special efforts, sometimes through commission or administrative intervention. Tafsir of sharkhs were written in the Ottoman period. However, special exegeses were also written, as in the Musannifek example. Alâüddîn Alî b. Muhammed b. Mes'ûd el-Bistâmî eş-Şâhrûdî is one of the expounders of the Ottoman period, made such an effort and wrote the aforementioned tafsir, which we tried to evaluate over the copies we have. Musannifek is one of Râzi's grandchildren. Şâhrûdî who started to write at an early age, wrote interpretations and compilations with his ability to write fast, intelligence power, scientific depth, knowledge effort and the way he handled the issues. His most important work is his tafsir. Musannifek; continued the classical tafsir tradition in terms of source, style, and method. He follows a method of tafsir in the order of mushaf surah. Musannifek interprets the surahs in different sections under main titles and subtitles in his exegesis. He explains almost every verse in terms of lexicon, logic, and grammar in his interpretation. Musannifek wrote his works in Arabic and Persian with the influence of the education he received, the literary culture and the political administration of the period. It is possible to see the reflections of this situation in his exegesis. Musannifek whose exegesis contains the traces of both the diraya and riwaya is quite remarkable with its explanations on literary subjects. He uses plain language in his interpretation and avoids repetitions and unnecessary explanations that will cause wordiness. His name was not mentioned in the famous expounders of the recent period. Katip Çelebi, Tâşköprîzâde and Bursalı Mehmed Tahir mentioned Musannifek in their works. In this study, we tried to include the subjects of the ulûmü'l-Qur'an each of which is a separate scientific study and examples of the method and Qur'anic approach of Musannifek. All this information shows us the competence of Musannifek in the interpretation of the Quran and the superior position of his commentary in terms of the ulûmü'l-Quran and the tafsir method. Ulûmü'l-Qur'an issues are important in understanding and interpreting the Quran correctly. In our research, only some of the subjects of ulûmü'l-Quran are included, considering that it will create sufficient opinion about Musannifek. Manuscript tafsir copies of Musannifek, almost all of which we tried to read are worthy of scientific research in terms of its subject, content, and method. In the handwritten copy of the tafsir written in Persian and Arabic seventy-five surahs of the Quran and five verses of the al-Baqara are commentated. Since it is a work of exegesis, the sciences and principles of the Quran are not specifically included. Nevertheless, Musannifek points to these issues. As can be understood from his tafsir, Musannifek is a productive commentator. He applied the basic subjects of ulûmü'l-Quran and tafsir to his interpretation in understanding and interpreting the Quran. The interpretation of Musannifek was not be completed or could not survive. In our article, the content, and features of Musannifek's interpretation are evaluated. The two copies of Musannifek's manuscript in Konya and Beyazit Manuscript Libraries can be accessed from the web page of the Turkish Manuscript institution. 


\section{Giriş $^{1}$}

Kur'ân; önünden ve arkasından asılsız hiçbir şeyin yaklaşamadığı yani önceki kutsal kitaplar tarafından tasdik edilen, eksiltme ve ziyadeleştirme anlamında sonsuza dek asla kendisine müdahale edilemeyecek olan bir kitaptır. ${ }^{2}$ Kur'ân'ın nüzûlünden itibaren ilk müfessiri olması hasebiyle öncelikle Hz. Peygamber, sonrasında da sahabe, tabiîn, etbâu'ttâbiîn ve onlardan günümüze kadar kimi zaman bir âyet, kimi zaman bir sûre, kimi zaman da tamamı olmak üzere Kur'ân tefsirlerinin yapıldığı görülmektedir. Hicrî ikinci asırdan itibaren Mukâtil b. Süleyman'la (öl. 150/767) birlikte müstakil tefsirler kaleme alınmış; Taberî (öl. 310/923) ve onu izleyen süreçte kaynak, yöntem ve yaklaşımları bakımından farklı tasniflerde eserler yazılmıştır. Tefsir tarihiyle ilgili klasik kaynaklarda Osmanlı tefsir müktesebatındaki az sayıda özgün ve orijinal esere dahi yer verilmemiş olmasından da hareketle o dönemde de genellikle şerh, haşiye ve ta'liklerin yazıldığı iddia edilmektedir. ${ }^{3}$ Fazlurrahman'ın (öl. 1988) da içerisinde bulunduğu bu iddianın savunucularına göre İslam'ın fikrî gelişimi ve Kur'ân'ın anlaşılmasında dil ve belâgat uğraşıları gereksiz görülmekte; şerh, haşiye, ansiklopedik bilgi ve derleme yaklaşımlarının üretkenliği engellediği belirtilmektedir. ${ }^{4}$ Bununla birlikte Musannifek örneğinde olduğu gibi her ne kadar tamamlanamamış veya bütün olarak günümüze ulaşamamış olsa da o dönemde bazı müstakil tefsirlerin yazıldığ da bir gerçektir. ${ }^{5}$

Herhangi bir bilim veya sanat dalının bilgi birikiminin öğrenilebilmesi veya anlatılabilmesi için belirli temel esas ve ilkeler bulunmaktadır. Fıkıh, Hadis ve Tefsir gibi ilim dallarında da doğru sonuca vâsıl olabilmek için bazı usûl ilkeleri mevcuttur. Kur'ân âyetlerini çeşitli yönleriyle inceleyerek onun doğru anlaşılmasına vesile olan konu, yöntem ve metotlara tefsir usûlü ilkeleri denilmektedir. ${ }^{6}$ Müstakil tefsir usûlü kaynaklarında ve özellikle tefsir mukaddimelerinde ele alınan bu tür kâidelerin, müfessirin metodu hakkında

1 Bu araştırmada, T.C. Kültür ve Turizm Bakanlığı Türkiye Yazma Eserler Kurumu Başkanlığı Konya Yazma Eser Kütüphanesi ve Beyazıt Yazma Eser Kütüphanesi'nden ücretsiz olarak temin edilen dijital görsellerden faydalanılmıştır.

2 Alâüddin Alî b. Muhammed b. Mes'ûd el-Bistâmî eş-Şâhrûdî(Musannifek), Tefsîru Musannifek, Konya Yazma Eser Kütüphanesi, Konya İl Halk Kütüphanesi, nr. 3759, vr. A69b; Ayrıca bk. el-Fussılet 41/42.

3 Bk. Mustafa Öztürk, “Osmanlı Tefsir Kültürüne Panoramik Bir Bakış”, Osmanlı Toplumunda Kur'ân Kültürü ve Tefsir Çalışmaları I, ed. Bilal Gökkır v.dğr., (İstanbul: İlim Yayma Vakfı, 2011), 92-122.

4 Fazlurrahman, İslam ve Çă̆gaşlık, çev. Alparslan Açıkgenç vd. (Ankara: Ankara Okulu, 1998), 91-94.

5 Bk. Kâtib Çelebi, Keşfü'z-zunûn 'an esâmi'l-kütüb ve'l-fünûn, (Beyrut: Dâru İhyâi't-Turâsi'l-Arabî, ts.), 1/458; Ümit Karaver, “Şeyh Ali el-Bistâmî’nin(Musannifek) Biyografisi ve Tefsir Alanındaki Çalışmaları”, Osmanlı'da İlm-i Tefsir, ed. Harun Abacı vd., (İstanbul: İsar, 2019), 90; Ersin Çelik, “Fatih Sultan Mehmet Han'ın Emriyle Yazılan Farsça Tefsir", Osmanlı Döneminde Tefsir, ed. Hidayet Aydar v.dğr., (İstanbul: Ensar, 2018), 1/148-149.

6 Muhsin Demirci, Tefsir Usûlü, (İstanbul: İFAV., 2018), 21. 
bilgi verdiği gibi onu doğru sonuca ulaştırmakta da önemli rol oynadı̆̆ Esbâbü'n-nüzûl, Nâsih-mensûh ve Fezâilü'l-Kur'ân gibi konuların bir kısmının ele alındığı kaynaklar olduğu gibi bütün bu konuların tamamının ele alındığı müstakil kaynaklar da bulunmaktadır. Musannifek de tefsir nüshasında sûreleri izah ederken zaman zaman bu konulara değinmektedir. ${ }^{7}$

Musannifek tefsirini şekil, muhteva ve diğer hususlar bakımından sayfa sayfa ele alarak tefsir ve tefsir usûlü perspektifinden incelediğimizde tefsirin kapak ve giriş kısmındaki yazılardan yazarın yaşadığı dönemde ve bizzat kendi kaleminden yazıldığı anlaşılmaktadır. Eserin dili Farsça ve Arapça olduğundan özellikle Arapça izahlardan Musannifek tefsirinin mahiyeti hakkında inceleme ve değerlendirmelerde bulunulmaktadır. Yükseköğretim Kurulu Başkanlığı Tez Tarama Programına bakıldığında Musannifek'in tefsiri haricindeki eserleri hakkında yüksek lisans ve doktora düzeyinde akademik çalışmalar yapıldığı görülmektedir. Musannifek'in biyografisi ve tefsir alanındaki çalışmaları ile ilgili makale bazında birkaç araştırma bulunmaktadır. Hayatı ve tefsirinin tarihi arka planı hakkında detaylı kronolojik bilgilerin verildiği bu makalelerde de tefsir çalışmaları ve farklı nüshalarının dökümü yapılmasına rağmen usûl ve içerikleri konusuna yeterince değinilmediği anlaşılmaktadır. ${ }^{8}$ Bu durumun tefsir araştırmacılarına çalışılacak bakir bir alan sağladığını belirtmekle birlikte çalışmamızın daha öncekilerin geldiği noktayı daha da ileriye taşıyacağı, Musannifek ve tefsirinin tanınmasına muhtelif yönlerden katkı sağlayacağı muhakkaktır.

\section{Musannifek ve Tefsiri}

Musannifek ve tefsiri başlığı altında, kendisini farklı alanlarda yetiştiren ve pek çok eser kaleme almış olan müfessirin hayatı ve eserleri ile tefsirinin muhteva ve metodik özelliklerine değinilmektedir. Önceliğimiz; söz konusu tefsir nüshası, metodu ve içerisindeki ulûmü'l-Kur'ân mevzuları olduğundan bu kısımda diğer konularla ilgili fazla teferruata girilmemektedir.

\footnotetext{
7 Araştırmamızın ilerleyen kısımlarındaki başlıklarda bu konuda örnekler verilmektedir.

8 Bk.Yahya Başkan, "Siyasi Mekân Değişikliğinin Eser Telifine Yansımasına Bir Örnek: Musannifek”, Doğu Araştırmaları, 10/1 (Ocak 2012), 117-122; Karaver, "Şeyh Ali el-Bistâmî", 77-88; Çelik, "Fatih Sultan Mehmet Han", 1/131-160.
} 


\subsection{Musannifek'in Hayatı ve Eserleri}

Alâüddîn Alî b. Muhammed b. Mes'ûd el-Bistâmî eş-Şâhrûdî h.803/m.1400 yılında Horasan'ın Bistâm beldesine bağlı Şâhrûd köyünde doğmuştur. Râzî'nin (öl. 606/1210) torunlarından olduğu için "er-Râzî”; nesep yönünden iki farklı cihetten Hz. Ebû Bekir ve Ömer'e dayandığ1 için de "el-Bekrî ve el-Umerî" diye nisbetlenmiştir. Fazileti, ilmî birikimi, zekâsı ve üstün kitabet yeteneği sayesinde erken yaşlarda eser yazmaya başlayan Şâhrûdî'ye küçük musannif anlamında "musannifek" lakabı verilmiştir. ${ }^{9}$ Farsça' da kelimelerin sonuna eklenerek o kelimeye küçültme ve tasgir anlamı katan bazı ekler vardır. Daha başka ekler bulunmakla birlikte bunlardan en meşhurları "جُ/çe", "ه/he" ve "كاك/ke" harflerinden oluşan eklerdir. ${ }^{10}$ Arapça'da yazar anlamındaki musannif/ مصنف kelimesinin sonuna eklenen, Farsça

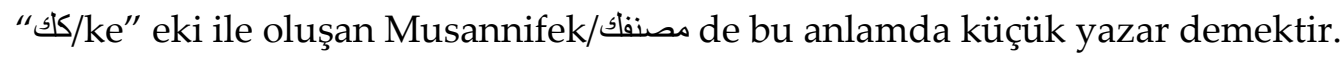

Şâhrûd köyünde dünyaya gelen Musannifek, daha önceki İslam âlimlerinin çoğunda olduğu gibi ilim yolunda seyahat etmiş ve Herat'a gelmiştir. Ömrünü ilim öğrenmek ve öğretmekle geçiren Musannifek; Edebî ilimler, Tasavvuf, Fıkıh, Hadis ve Tefsir gibi aklî ve naklî ilimleri farklı hocalardan ders almak suretiyle kendi döneminin önde gelen ilim adamlarından biri olmuştur. Konya, Karaman, Bursa ve İstanbul'da müderrislik yapan Musannifek, Fatih Sultan Mehmet'e (öl. 886/1481) de mülaki olmuştur. Onun talebi üzerine onun ismine atfen "el-Muhammediyye" adıyla da bir eser kaleme almıştır. Oldukça üretken ve hızlı yazma kabiliyetine sahip olan; telif, derleme ve şerh olmak üzere pek çok eser yazan Musannifek 1470 yılında İstanbul'da vefat ederek Eyüp kabristanlığına defnedilmiştir. ${ }^{11}$

Ömer Nasuhi Bilmen (öl. 1971), sahabe-i kiramdan itibaren Kur'ân'daki murâd-1 ilâhîye tercümanlık yapmış müfessirleri irtihallerine ve yaşadıkları asırlara göre tasnif ederken dokuzuncu tabakadaki müfessirler arasında Musannifek'e de yer vermektedir. ${ }^{12}$ Osmanlı dönemi meşhur biyografi ve bibliyografya yazarı Mehmed Tâhir (öl.1925) de eserinde Osmanlı dönemi müelliflerinden biri olarak Musannifek'ten bahsetmektedir.13

9 Ebü'l-Ferec Abdü'l-Hayy b. İ'mâd el-Hanbelî, Şezerâtü'z-zeheb fî ehbâri men zeheb, thk. Abdülkadir el-Arnâût, (Beyrut: Dâru İbn Kesîr, 1413/1993), 9/476; Tâşköprîzâde Ahmed Efendi, Miftâhu's-sa'âde ve misbâhu's-siyâde fî mevzîu'âti'l-'ulûm, (Beyrut: Dâru'l-Kütübi'l-'Ilmî, 1405/1985), 1/174; Tâşköprîzâde, eş-Şekâiku'n-Nu'mânî fî 'Ulemâi'd-Devleti'l-'Osmânî (Beyrut: Daru'l-kitabi'l-Arabî, ts.), 1/100; Hayruddîn b. Mahmûd ez-Ziriklî, el-A'lâm, (Beyrut: Dâru'l-'Ilm li'l-melâyîn, 1422/2002), 5/9.

10 İsmail Bangi, Farsça Dilbilgisi, (Ankara: A.Ü İlahiyat Fakültesi Yay., 1390/1971), 25.

11 Tâşköprîzâde, eş-Şekâik,1/101-102.

12 Bk. Ömer Nasuhi Bilmen, Büyük Tefsir Tarihi/Tabakâtü'l-Müfessirîn, (İstanbul: Ravza, 2008), 1/197.

13 Bk. Bursalı Mehmed Tâhir, Osmanlı Müellifleri, (İstanbul: Matbaa-i Âmire, 1333/1914), 2/32. 
Küçük yaşlarda eser telif etmeye başladığını ifade ettiğimiz Musannifek'in (öl. 875/1470) Türkçe’ye de tercüme edilen Sarf, Nahiv, Belâgat, Kelam, Hadis, Mantık, Fıkıh, Akaid, Tasavvuf ve Tefsir gibi farklı alanlarda onlarca eseri bulunmaktadır. ${ }^{14}$ Genellikle Farsça ve Arapça olarak kaleme aldığı eserlerinin ekserisi başka eserlere yapılan şerh ve hâşiyelerden ibarettir. Bu durumda almış olduğu eğitim yapısı, yaşadığı dönemin ilmî yazın geleneği ve siyasi coğrafya değişikliği gibi faktörlerin etkili olduğu kanaatindeyiz. Söz konusu eserlerinin bir kısmını şu şekilde sıralamak mümkündür: eş-Şifâ fî tefsîri kelâmillâhi'lmünzel mine's-semâ(Muhammediyye/Mülteka'l-bahreyn), el-Hudûd ve'l-ahkâm, Hallü'r-rumûz fi keşfi'l-künûz, Hâşiye a'lâ şerhi A'kâidi'n-Nesefî, Hâşiye a'le'l-Keşşâf, Hâşiye a'le'l-Mutavvel, Hâşiye a'lâ şerhi'l-miftâh li't-Teftâzânî, Hâşiye a'lâ levâmi'i'l-esrâr şerhu metâli'i'l-envâr, el-Kevâkibu'ddurrî şerhu kasîdeti'l-burde, Şerhu'l-Hidâye, Şerhu'l-Vikâye, Şerhu'l-Merâh, Şerhu'l-Mesâbîh li'lFerrâ el-Bagâvî, Şerhu'l-Mevâkıf, Şerhu'l-Emâlî, Şerhu'l-A'lâka, Şerhu'ş-Şemsî, Şerhu'l-Kasîdeti'la'yniyyetü'r-rûhî fi'n-nefs, er-Reşâd fî şerhi irşâdi'l-hâdî li't-Teftâzânî, Şerhu'l-Mesnevî li-Celâliddîn er-R̂̂mî, Şerhu'l-Lübâb fi'n-nahv, Şerhu'l-Misbâh, Tuhfetü's-selâtîn, Tuhfetu'l-vuzerâ, Tuhfe-i

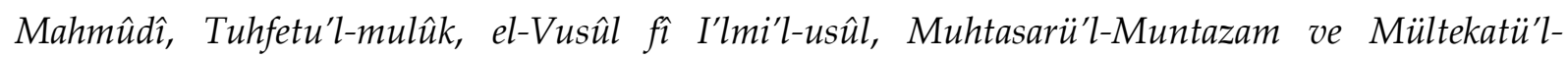
mültezem, et-Tahrîr şerhu kitâbi'l-Pezdevî fì usûli'l-fikh, Tefsîru Musannifek.

Bunlar arasında "eş-Şifâ" adlı eser, "Mülteka'l-bahreyn" veya Fatih Sultan Mehmet adına telif edildiği için "el-Muhammediyye" olarak da tanınmaktadır. ${ }^{15}$ Kâtib Çelebi (öl. 1067/1657), bunları iki farklı eser olarak kaydetmektedir. ${ }^{16}$ Kaynaklar, Şâhrûdî'nin burada bahsedilen tefsir eserlerinin dışında başka eserlerinin olduğunu da ortaya koymaktadır. ${ }^{17}$ Taftazânı̂’nin İrşâdü'l-Hâdî adlı eserine yazmış olduğu şerh ile alakalı Halil Özcan tarafından bir doktora tezi hazırlanmıştır. Ayrıca el-Hudûd ve'l-Ahkâm, Şerhu'l-Emâlî, el-Kevâkibu'd-durrî şerhu kasîdeti'l-burde ve Şerhu'l-Mesnevî li-Celâliddîn er-Rûmî adlı eserleri hakkında da yüksek lisans düzeyinde akademik çalışmalar yapılmıştır. ${ }^{18}$

14 Bk. Bilmen, Tabakâtü'l-Müfessirîn, 2/600; Sinan Taşdelen, Musannifek Alaaddin Ali Bin Muhammed'in Mevlânâ'nın Mesnevî'si ile İlgili Risâlesi, (Konya: Selçuk Üniversitesi, Sosyal Bilimler Enstitüsü, Doktora Tezi, 2007), 28.

15 Ziya Demir, Osmanlı Müfessirleri, (İstanbul: Ensar Neşriyat, 2006), 122-127; M. Kâmil Yaşaroğlu, "Musannifek”, Türkiye Diyanet Vakfi İslam Ansiklopedisi, (İstanbul: TDV, 2006), 31/239-240.

16 Bk. Kâtib Çelebi, Keşfü'z-zunûn, 1/458.

17 Bk. Taşdelen, Musannifek, 32.

18 Bk. Abdullah Bedeva, Alâuddin Ali b. Muhammed el-Bistâmî Musannifek'in Kaside-i Bürde Şerhi'nin Tahkiki, (İstanbul: Marmara Üniversitesi, Sosyal Bilimler Enstitüsü, Yüksek Lisans Tezi, 2012), 7. 


\subsection{Tefsîru Musannifek}

Osmanlı dönemi âlimlerinden olan Musannifek'in muhtelif eserlere yazmış olduğu şerh ve hâşiyeler bulunmaktadır. Bunlar içerisinde kanaatimizce dili, üslubu, yöntemi ve muhtevası bakımından Musannifek'i öne çıkaran en önemli eseri tefsiridir. Musannifek'in tefsir çalışmalarında dil açısından Zemahşerî (öl. 538/1144); Kur'ân hakikatlerinin keşfi noktasında da Râzî’nin (öl. 606/1210) eserlerinin etkisini görmek mümkündür. ${ }^{19}$ Onun tefsiri ile ilgili farklı görüşler bulunmaktadır. Araştırmalarımız sonucunda Türkiye Yazma Eserler Kurumu Başkanlığı'nın web sayfasındaki detaylı katalog taraması neticesinde "Tefsîru Musannifek" ismiyle ve 42 Kon 3759 arşiv neşriyat numarasıyla Konya Yazma Eser Kütüphanesi'nde kayıtlı olan eserin müstensihi Muhammed b. Abdurrahman b. Muhammed olarak kaydedilmiştir. İstinsah ve telif tarihi tespit edilememiş olsa da nüsha kapağındaki “ ibaresinden hareketle söz konusu eser Musannifek'in hattı olarak düşünülmektedir. Sayfalar üzerindeki numaralandırmalardan anlaşılacağı üzere Musannifek'in yazma tefsir nüshası 380 varaktan oluşmaktadır. Nüshanın ilk sayfasına klasik el yazma eserlerde karşılaşılan, kitapları haşerattan koruma amacı taşıyan, Süryanice' de haşeratı yok etmekle görevli bir meleğin, kitap kurtları şeyhinin veya bir bitki isminin adı olduğu ifade edilen "كيبكج/kebîkec" kelimesi ile birlikte " يا حي يا حفيظ يا كبيكج يا حليم يا "ibaresi yazılmıştır. ${ }^{20}$

Beyazıt Kütüphanesi'nde ulaşabildiğimiz, 86 varaktan oluşan bir diğer tefsir nüshasında ise Bakara sûresi'nden bazı âyetlerin tefsiri yapılarak tefsir usûlü ve ulûmu'lKur'ân ile ilgili izahlara değinilmektedir. Beyazıt Kütüphanesi'ndeki bu nüsha ise Veliyyuddîn Efendi koleksiyonu ve 169 arşiv neşriyat numarasıyla kayıtlanmıştır. ${ }^{21}$ Elimizde Musannifek'e ait iki nüsha olduğundan araştırmamızda Konya'daki nüsha "A", Beyazıt'taki nüsha ise " $\mathrm{B}$ " harfiyle dipnotta gösterilecektir. Taşınma ve benzeri sebeplerden mütevellit olarak tespit edebildiğimiz iki nüsha haricinde herhangi bir kaydına rastlayamadığımız Musannifek tefsirinin bu alanda yeterince tanınmaması, usûl ve metot açısından hakkında henüz bir araştırma yapılmamış olması çalışmamızın önemini artırırken söz konusu tefsir nüshalarının tarihin tozlu raflarında unutulmasına da mâni olacaktır.

19 Bk. Karaver, “Şeyh Ali el-Bistâmî”, 78.

20 Musannifek, Tefsîr, vr. A1b.

21 Alâüddin Alî b. Muhammed b. Mes'ûd el-Bistâmî eş-Şâhrûdî(Musannifek), Tefsîru Musannifek, Beyazıt Yazma Eser Kütüphanesi, Veliyyuddîn Efendi, nr. 169. 
Kâtip Çelebi'nin anlattı̆̆ına göre yalnızca bazı nüshalarına ulaşabildiğimiz söz konusu tefsir Farsça yazılmış ve büyük ciltlerdedir. "el-Muhammediyye" diye de isimlendirilmiştir. Oldukça uzun ve ayrıntılı, fakat sade bir dil kullanılmıştır. Fatih Sultan Mehmet Hân'ın talebi üzerine hicrî 863 yılında yazılmıştır. Hacim olarak büyük ve kıymetli bir eserdir; fakat eksik kalmış, tamamlanamamıştır. Kâtip Çelebi, Musannifek'in bundan başka "Mülteka'l-bahreyn" isminde bir başka tefsir eserinin daha bulunduğunu ifade etmektedir. Müfessir, el-Kevâkibu'd-durrî adlı Kasîde-i Bürde şerhindeki nahvî ilkeleri bu kitaba uygulamaya çalışmıştır. ${ }^{22}$ Kâtib Çelebi'nin iki farklı eser olarak naklettiği Mülteka'lbahreyn adlı eserde Fâtiha sûresi tefsir edilmiş ve nahiv kâidelerine fazlasıyla yer ayrılmışken; el-Muhammediyye adlı eserde ise Mürselât sûresi'nden Nâs sûresi'ne kadarki sûreler tefsir edilmiştir. ${ }^{23}$ Kâtip Çelebi'nin ifadelerinden Tefsîru Musannifek ile elMuhammediyye'nin aynı eserler olduğu anlaşılmaktadır. Mülteka'l-bahreyn ise farklı bir eser olarak durmaktadır. Çünkü bizim incelediğimiz nüshada Sâd sûresi'nden Nâs sûresine kadarki sûreler bulunmaktadır. Fakat Ömer Nasuhi Bilmen, eş-Şifâ adlı eserin, Fatih'in isteği üzerine yazıldığından Muhammediyye; zahir ve gayr-i zahir hakikatleri izah ettiğinden de Mülteka'l-bahreyn ismiyle anıldığını belirtmektedir. Dolayısıyla O'na göre bu üç isimde belirtilen eserler birbirinden farklı değil, birbirinin aynıdır. ${ }^{24}$

Musannifek, yazın hayatının bir noktasından sonra artık Farsça eser yazmamaya karar vermiş olsa da tefsirinin çoğunluğunda Farsça ibarelerin bulunduğu görülmektedir. ${ }^{25}$ Yanlış anlaşılmaya mahal vermemek adına Tefsîru Musannifek tabiriyle, yukarda bahsedilen yazma eser kütüphanelerindeki kayıtlardan hareketle nasıl bir tetkik ve tahkikle isimlendirildiği bilinmeyen mezkûr iki yazma nüshayı kastettiğimizi belirtmekte fayda görmekteyiz. Çünkü nüshaların temellük kaydı ve zahriyelerinde isimleriyle alakalı belirgin bir ifade bulunmamaktadır. Şekil olarak Beyazıt Kütüphanesi'ndeki nüsha, müellif hattı olup dağılmış cildin sırtı meşin yamalı ve mukavva kapaklar kahverengi kâğıtla kaplıdır. Sayfalar genellikle yirmi bir satırdan oluşmaktadır. فان قيل gibi başlıklar kırmızı renkle fark edilir hale getirilmiştir. Konya nüshasının zahriyesinde de "تفسير مصنفك باخط مصنفك ibaresi kayıtlıdır. Satır sayısı genel olarak bütün varaklarda on yedidir. Âyetler siyah mürekkep ve kalın bir uç kullanılarak daha büyük karakterde yazılmıştır. Satır formundan bağımsız

\footnotetext{
22 Bk. Kâtib Çelebi, Keşfü'z-zunûn, 1/458.

23 Bk. Taşdelen, Musannifek, 32.

24 Bilmen, Tabakâtü'l-Müfessirîn, 2/599; Demir, Osmanlı Müfessirleri, 124.

25 Bk. Kâtib Çelebi, Keşfü'z-zunûn, 1/458; Tâşköprîzâde, eş-Şekâik,1/101.
} 
olarak sayfa kenarlarına haşiye mahiyetinde bazı notlar ilave edilmiştir. Nüsha sonundaki ferağ kaydında Muhammed b. Abdurrahman b. Muhammed tarafindan istinsahının tamamlandığı kaydedilmiştir. Eser, sülüs hatlı, çeharkûşe ciltli olup sırt sertap kahverengi meşin, ebrulu ve şirazeli mıkleplidir. Her iki nüsha muhteva ve üslup açısından birbirinin aynı olsa da fiziksel özellikleri bakımından belirgin farklara sahiptir.

Mekân, zaman ve mevcut şartların tesiriyle kabiliyet, ihtisas ve mevhibî düşünceler sayesinde Kur'ân'ın nüzûlünden günümüze kadar tefsir sahasında muhtelif eserler yazılmıştır. Orijinal ve özgün olanlar bulunmakla birlikte bilimsel ve sosyal veriler; kültürlerin, ekollerin, insanların ve bunların ürünlerinin birbirlerinden etkilendiklerini ortaya koymaktadır. Bu bağlamda şunu ifade edebiliriz ki Musannifek, tefsirinde sûreleri

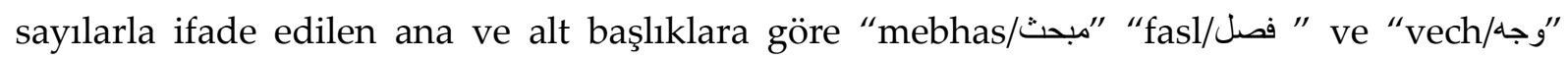
şeklinde faklı bölümlerde tefsir etmektedir. ${ }^{26}$ İzaha ihtiyaç duyulan âyet ve konuların durumuna göre bunların sayısı değişmektedir. Bu yönüyle üslûbu, Râzî’nin Mefâtîhu'lgayab'ına benzemektedir. Sûre isimleri, indirildikleri yerler ve faziletleriyle ilgili rivâyetlere yer vermektedir. Fakat bu rivâyetleri naklederken senetlerini tam olarak zikretmemektedir. Örneğin Bakara sûresi'ni tefsirinde söz konusu sûreyi bu şekilde ilk isimlendirenin Hz. Peygamber olduğunu belirtirken, sonundaki iki âyeti okumanın o gece için kişiye yeterli olacağını anlatan hadis-i şerif rivâyetini kullanmaktadır. ${ }^{27}$ Kullandığı rivâyetlerin kaynağı ve râvîleri hakkında da zaman zaman bilgi veren Musannifek, bu rivâyeti Ahmed b. Hanbel (öl. 241/855), Buhârî (öl. 256/870) ve Müslim'in (öl. 261/875) tahriç ettiklerini belirtmektedir.28 Bazen de rivâyetlerin isnadının kuvveti ve sahihlik bakımından üstünlükleri konusunda tercihini ortaya koymaktadır.29 Daha pek çok yerde "خبر/ve fî haber" cümlesiyle rivâyetleri naklederek aynı metodu izlemesi kaynak ve yöntem bakımından Musannifek tefsirinin rivâyet tefsiri özelliği gösterdiğine delâlet etmektedir. ${ }^{30}$ Fakat bununla yetinmeyip dil ve edebiyat gibi enstrümanlardan faydalanması aynı zamanda dirayet tefsiri kategorisinde değerlendirilebileceğini de göstermektedir. ${ }^{31}$ Kurtubî (öl. 671/1273) vb. baz1

\footnotetext{
26 Musannifek, Tefsîr, vr. B42a-B42b-A80a-A352b.

27 Buhârî, Ebû Abdillâh Muhammed b. İsmâîl b. İbrâhîm, el-Cu'fî, el-Câmu's-sahîh, thk. M. Züheyr b. Nâsır, (b.y.: Dâru Tavkı'n-Necât, 1422/2001) "Meğ âzzî̀", 12.

28 Musannifek, Tefsîr, vr. B3a-B23b-B24b-A260a.

29 Musannifek, Tefsîr, vr. A246a-b.

30 Musannifek, Tefsîr, vr. B35a-A17a-A67b-A68a-A234a-A374b-A66a-b-A81b.

31 Musannifek, Tefsîr, vr. B42a-B44a.
} 
müfessirler ile Halil b. Ahmed'in (öl. 175/791) Kitâbu'l-A'yn'ına atıflar yapmaktadır.32 Hakeza Mâlik b. Enes'in (öl. 179/795) Muvatta'ından da nakillerde bulunmaktadır. ${ }^{33}$

Birinci defterde Fâtiha sûresi ile besmelenin tefsirinin yapıldığını, bu sebeple konuyu uzatmaya veya tekrar etmeye gerek olmadığını belirtmektedir. Aynı şekilde birinci defterde kıraatlerle ilgili izahlarda bulunduğunu ifade etmektedir, fakat elimizdeki nüshalarda söz konusu defter hakkında herhangi bir malumat bulunmamaktadır. Muhtemelen bundan önceki yazma nüshayı kastetmektedir. ${ }^{34}$

Tefsirinde tercih veya tenkit maksadıyla bazı görüşleri naklettiğini, fakat daha detaylı bilginin daha önce yazmış olduğu Hâşiye a'le'l-Keşşâf adlı eserinde bulunduğunu belirterek

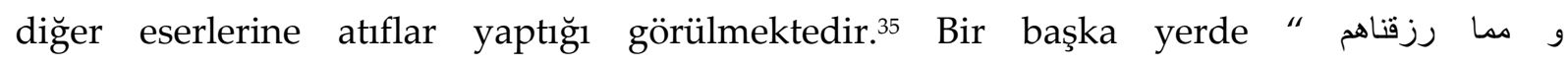

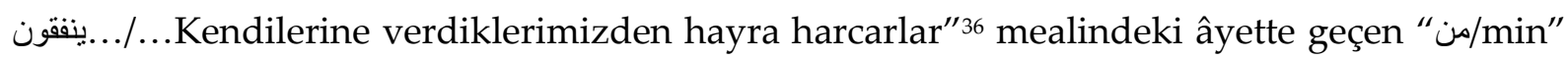
harf-i cerrinin teb'îydıyye olduğunu belirtirken de yine kendisine ait "Şerhu'l-Lübâb" adlı eserine atıfta bulunmaktadır. ${ }^{37}$ Te'vîl ilmi ile alakalı olarak ğayb konusu bağlamında En’âm sûresi 59. âyeti tefsir ederken "Tefsîr-i kebîr sahibi dedem zikretti ki..." diyerek Râzî’ye atıf yapmaktadir. ${ }^{38}$

Musannifek tefsirinde öne çıkan özelliklerden biri de "إنّ القرآن يفسر بعضه بعضا/ Elbette Kur'ân'ın bir kısmı bir kısmını tefsir eder"39 kâidesi doğrultusunda Kur'ân âyetlerindeki ince manaların kimi zaman aynı sûreden kimi zaman da farklı sûrelerden âyetlerle tefsir edilmesidir. ${ }^{40} \mathrm{Bu}$ sayede âyetler arasındaki irtibat ve anlam farklılıkları muhatabın zihnine yakınlaştırılmaya çalışılmaktadır. Ayrıca pek çok yerde “فان قيل/O halde denilir ise veya düşünülür ise..." şeklindeki ifadelerle akla gelebilecek muhtemel soru ve tereddütler izah edilmeye çalışılarak farazî tefsir de diyebileceğimiz bir anlatım kullanmaktadır. ${ }^{41}$ Hakeza, Yüce Allah'ın iki defa öldürmesi ve diriltmesi konusundaki iki görüşü vererek bunlardan en doğru olanı hakkında tercihte bulunması da bir başka dirayet özelliğini yansıtmaktadır. ${ }^{42}$

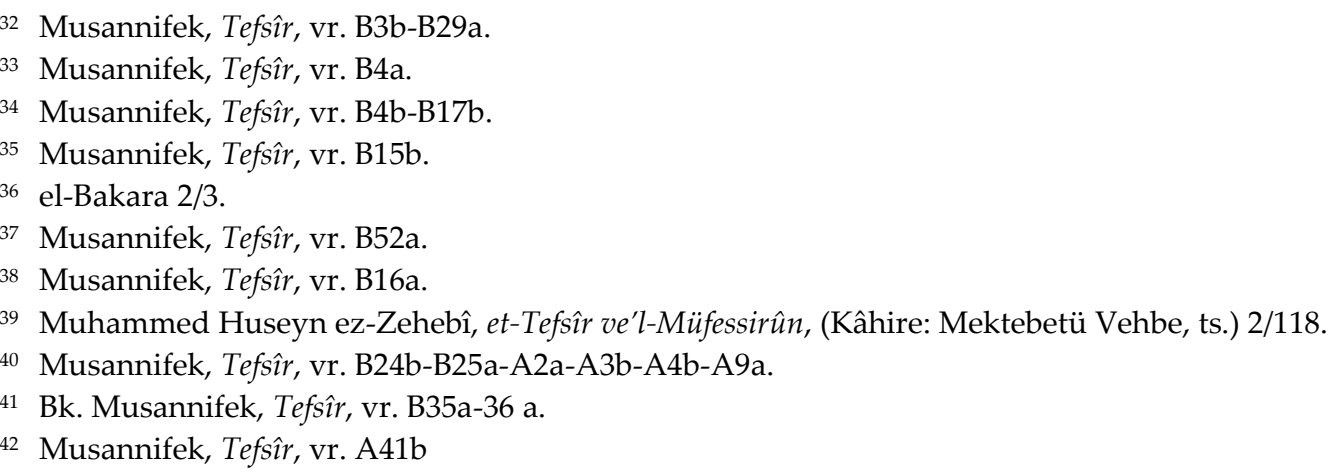


Musannifek tefsirinde göze çarpan durumlardan biri de hemen her âyeti lügat, nahiv, sarf, me'ânî, beyân ve mantık ilmine taalluk eden yönleriyle izah etmeye çalışmasıdır. ${ }^{43}$ Tasavvufî anlamda takva kelimesini izah ederken kapsamının genişliğine, Allah'a kulluk ve yakınlık vesilesi her davranışın takva olduğuna değinmekte, verâ' kavramıyla mukayesesini yaparak Hasan-1 Basrî (öl. 110/728), İbrahim Edhem (öl. 161/778) ve Kuşeyrî (öl. 465/1072) gibi işârî tefsir konusunda meşhur isimlerin görüşlerini nakletmektedir. ${ }^{44}$ Nefsin; cimrilik ve tembellik yapmadan ancak Allah'ı zikretmekle arındırılabileceğini, hayatiyetinin bu şekilde

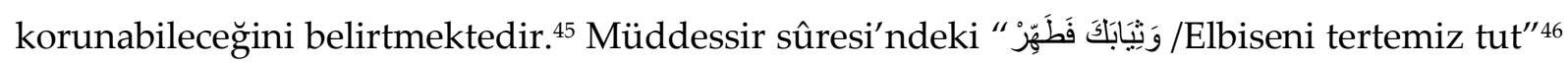
ifadesini elbise değil de 'davranışlarını güzelleştir, ahlakını süsle' şeklinde yorumlaması Musannifek' teki bir başka işârî tefsir özelliği örneğidir. ${ }^{47}$

Aynı şekilde Musannifek tefsirinin dikkat çeken özelliklerinden bir diğeri de lafızlarda veya kıssalardaki mücmel bırakılan hususların izahında isrâiliyyâtın hemen hemen hiç kullanılmamış olmasıdır. Bir diğer özellik ise kelime anlamlarının izah edilirken Mütenebbî (öl. 354/965) ve A'şâ (öl. 7/629[?]) gibi Arap şairleri ve diğer şairlerden istişhatta bulunulmasıdır. ${ }^{48}$

Musannifek'in, ilk dönemlerde olduğu gibi tefsir anlamında te' vîl lafzını kullanması da dikkat çekicidir. Tefsirinin bazı yerlerinde âyet-i kerîmeleri verdikten sonra "تأويله" veya

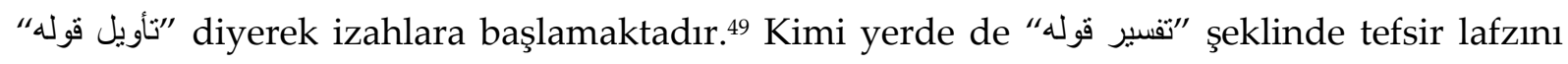
kullanarak âyetleri açıklamaktadır. ${ }^{50}$

\subsection{Muhteva ve Metodik Özellikleri}

Yazma eserler kütüphanesi kayıtlarındaki taramalarımız sonucunda ulaşmış olduğumuz Konya Yazma Eser Kütüphanesi'ndeki söz konusu nüshada Musannifek, mushaf sûre sırasına göre bir tefsir yöntemi izlemektedir. Bu minvalde yukarda özellikleri bahsedilen nüshada Sâd sûresi'nden başlayarak Nâs sûresi'ne kadarki sûrelerin tefsirini yapmaktadır. Nüshadaki sûre isimleri ve varak numaraları ise şöyledir: Sâd sûresi (A5a.), Zümer sûresi (A18b.), Secde sûresi (A63b.), Şûrâ sûresi (A78a.), Zuhruf sûresi (A92b.), Duhân

43 Örnek olarak bk. Musannifek, Tefsîr, vr. B42a-42b-B44a

44 Musannifek, Tefsîr, vr. B46a-B46b-A239b.

45 Musannifek, Tefsîr, vr. A350a.

46 el-Müddessir 74/4.

47 Musannifek, Tefsîr, vr. A285b.

48 Musannifek, Tefsîr, vr. A6a-A6b-A46a-A73a-A84b-A285b-A291a-A350a.

49 Musannifek, Tefsîr, vr. A285b-A350b-67b-71b-74a-A63a-A64a-A64b.

50 Musannifek, Tefsîr, vr. A236b-A296a-A76a. 
sûresi (A106b), Câsiye sûresi (A113a.), Muhammed sûresi (A130a.), Fetih sûresi (A139a.), Hucurât sûresi (A149b.), Kâf sûresi (A155a.), Zâriyât sûresi (A163a.), Tûr sûresi (A170a.), Necm sûresi (A174b.), Kamer sûresi (A184a.), Rahmân sûresi (A193a.), Vâk1â sûresi (A202b.), Hadîd sûresi (A212b.), Mücadele sûresi (A223a.), Haşr sûresi (A230b.), Mümtehine sûresi (A238b.), Saf sûresi (A246a.), Cum’â sûresi (A250a.), Münâfikûn sûresi (A255a.), Teğâbun sûresi (A258a.) Talak sûresi (A262a.), Tahrim sûresi (A267b.), Mülk sûresi (A273a.), Kalem sûresi (A277b.), Hakka sûresi (A284a.), Meâric sûresi (A288b.), Nûh sûresi (A293a.), Cin sûresi (A296b.), Müzzemmil sûresi (A302b.), Müddessir sûresi (A307a.), Kiyâme sûresi (A312a.), İnsan sûresi (A317a.), Mürselât sûresi (A323b.), Nebe' sûresi (A330a.), Nâziât sûresi (A334a.), Abese sûresi (A339a.), Tekvîr sûresi (A343b.), İnfitâr sûresi (A346b.), Mutaffifîn sûresi (A348b.), İnşikâk sûresi (A351b.), Burûc sûresi (A354b.), Târık sûresi (A357a.), A'lâ sûresi (A359a.), Ğâş̧iye sûresi (A361b.), Fecr sûresi (A364b.), Beled sûresi (A369b.), Şems sûresi (A372a.), Leyl sûresi (A374a.), Duhâ sûresi (A376a.), İnşirâh sûresi (A378b.), Tîn sûresi (A380a.), Alâk sûresi (A381b.), Kadr sûresi (A383a.), Beyyine sûresi (A384b.), Zilzâl sûresi (A386a.), Âdiyât sûresi (A388a.), Kâri’a sûresi (A389b.), Tekâsür sûresi (A390a.), Asr sûresi (A391b.), Hümeze sûresi (A392a.), Fîl sûresi (A393a.), Kureyş sûresi (A393b.), Mâ'ûn sûresi (A395a.), Kevser sûresi (A396a.), Kâfirûn sûresi (A396b.), Nasr sûresi (A343b.), Tebbet sûresi (A398a.), İhlas sûresi (A399b.), Felâk sûresi (A400b.), Nâs sûresi (A402b.).

Beyazıt Kütüphanesi'nden temin ettiğimiz el yazma nüshasında ise Bakara sûresi'nin ilk beş âyetine değinilmektedir. 56. varakta "إنقطعت و انتهت هذه القطعت هناء /Bu k1sım burada kesildi ve sona erdi" denilmektedir. Devamında ise herhangi bir konu başlı̆̆ı kullanılmaksızın " اله/bismillah" ibaresindeki lafzatullah, isim kelimesi ve baştaki "ب/bâ" harf-i cerrinin izahı yer almaktadır. ${ }^{51}$ Her ne kadar Keşfü'z-zunûn'da Musannifek tefsirinin yazı dilinin Farsça olduğu söylenmiş olsa da eser incelendiğinde dil tercihinde herhangi bir ölçütün bulunmaksızın Arapça ve Farsça karışık yazıldığıı, Arapça anlatılan konunun bir anda Farsça devam ettiği ve Arapça'nın inceliklerinin izah edildiği yerlerin büyük bir yekûn tuttuğu görülmektedir. Söz konusu tefsir nüshasına bakıldığında âyetlerin tefsirinde Kur'ân'daki diğer âyetlerin, Hz. Peygamber'in hadislerinin, kimi zaman da sahabe, tâbiîn ve daha sonraki nesillerden görüşlerine itibar edilen kimselerin sözlerinin nakledilerek rivâyet tefsirinde görülen bir yöntemin kullanıldığı anlaşılmaktadır. Bunun yanında bazı tenkitlerde

51 Musannifek, Tefsîr, vr. B56a-B56b. 
bulunulması, Arapça, Sarf, Nahiv ve Belâgat esaslarına yer verilmesi tefsirinde dirayet yönteminin izlendiğini de göstermektedir. ${ }^{52}$

\section{Tefsîr-i Musannifek'teki Bazı Ulûmü'1-Kur'ân ve Tefsir Usûlü Kâideleri}

Tefsir ilmi, konusunun Kur'ân olması ve onunla meşguliyeti sebebiyle diğer ilimlerden kıymetlidir. İslam ilim ve yazın kültüründe diğer alanlardan farklı olarak fıkıh ve hadis gibi bazı ilimlerin usûlü bulunmaktadır. Tefsir ilminde de müfessir açısından bir ustanın elindeki alet edevat niteliğinde de değerlendirilebilecek bazı kâideler vardır. Tefsir usûlü ve tarihi kaynaklarında sayıları farklılık arz eden, bir kısmı Kur'ân'ın lafzı, bir kısmı anlamı, bir kısmı da tarihi içerikli olan bu ilkeler Kur'ân'ı doğru anlayıp yorumlama faaliyetinde önem arz etmektedir. ${ }^{53}$ Kimi zaman müstakil kitaplarda, kimi zaman da tefsir mukaddimelerinde zikredilen temel ulûmü'l-Kur'ân maddelerinin uygulamalarını Musannifek tefsirinde de görmek mümkündür.

\subsection{Esbâbü'n-Nüzûl}

Esbâbü'n-nüzûl/nüzûl sebepleri; Hz. Peygamber hayattayken meydana gelen, Kur'an'ın sûre veya âyetlerinin inmesine neden olan soru, olay ve durumlardır. ${ }^{54}$ Kur'ân'1 doğru anlamaya yarayan ulûmü'l-Kur'ân maddelerinden biri olarak kitaplarında bu konuya ayrı bir yer ayıran müfessirler bununla ilgili müstakil eserler de yazmışlardır. ${ }^{55}$ Bir sözün kime, nerede, niçin ve nasıl söylendiği elbette önemlidir. Bu nedenle ilâhî bir kelam olan Kur'ân âyetlerinin hüküm ve delaletlerinin tespitinde onun nüzûlüne neden olan olay ve durumların göz önünde bulundurulması elzemdir. Kur'ân'da ahkâm âyetlerinin özel bazı durum ve sebeplere bağlanmış olması o lafızla anlatılan hükümlerin manasının umumî olmasına mâni değildir. Çünkü lafız sebepten daha umumidir. ${ }^{56}$ Tefsir usûlünün önemli konularından biri olması nedeniyle Musannifek de tefsirinde bu konuya değinmektedir. Tefsirinde 281. âyet hariç Bakara sûresi'nin tamamının Medine'de nazil olduğunu

52 Bk. Musannifek, Tefsîr, vr. A2b.

53 Bk. Süyûtî, Ebü'l-Fazl Celâlüddîn Abdurrahman b. Ebî Bekr b. Muhammed el-Hudayrî, el-ïtkân fî u'lûmi'lKur'ân. thk. F. Ahmed Zemerlî, (Beyrut: Dâru'l-Kitâbi'1-Arabî, 1427/2007), 448-851; Demirci, Tefsir Usûlü, 21129.

54 Bk. Ebû Abdilazîz Kutbüddîn Şah Veliyyullâh Ahmed b. Abdirrahîm b. Vecîhiddîn ed-Dihlevî, el-Fevzü'l-kebîr fî usûli't-tefsîr, (Dımeşk: Dâru'l-ğavsânî, 1427/2007), 69-71.

55 Ebû Abdillâh Bedrüddîn Muhammed b. Bahâdır b. Abdillâh et-Türkî el-Mısrî el-Minhâcî ez-Zerkeşî, el-Burhân fî u'lûmi'l-Kur'ân, thk. Ebu'l-Fadl İbrahîm, (Beyrut: Dâru İhyâi'l-Kütübi'l-A'rabî, 1376/1957), 1/22.

56 Süyûtî, el-ítkân, 85. 
belirtmektedir. ${ }^{57}$ Sahih hadislerde sabit olduğu üzere ve İslam âlimlerinin açıkladığı gibi Kur'ân'ın ilk nâzil olan sûresi Alâk sûresi'dir. Ayrıca bu durum ilk inen sûrenin Fâtiha veya Müddessir sûresi olduğu şeklindeki düşüncelere de aykırı değildir. Çünkü bu husustaki

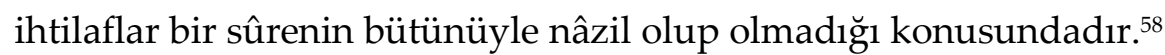

Mekke'deki bir olayı Medenî sûreye; Medine'deki bir olayı da Mekkî sûreye nüzûl sebebi göstermek gibi bazı tefsirlerde şahit olduğumuz bir hata söz konusudur. Buna dikkat eden Musannifek, hezimete uğramış gruptan bahseden Sâd sûresi 11. âyetin Mekke'de nazil olduğunu, fakat olayın Bedir gününde gerçekleştiğini söylemektedir. ${ }^{59}$ Şöyle ki, bağlam yorum ekseninde âyetin sibâkını göz önünde bulundurunca Hz. Peygamber ve Kur'ân aleyhine bir araya gelen müşrik gürûhun maksut olabileceğini ifade etmek de mümkündür.

Musannifek; Haşr sûresi'ni tefsir ederken sûrenin isimlendirilmesi, inmesine neden olan nüzûl ortamı, müslümanlar aleyhine birleşen topluluklar ve bunların müşriklerle ilişkileri gibi konulardan etraflıca bahsederek esbâb-1 nüzûl ilkesinin tatbiki konusunda bir yorum zemini oluşturmaktadır. ${ }^{60}$ Müstakil bir âyetin nüzûl sebebi bağlamında, "Onlar Allah'ı gereği gibi takdir edip tanımadılar. Kıyamet günü bütün dünya onun avucundadır; gökler de onun kudret elinde dürülüp bükülmüştür. Allah müşriklerin koştukları ortaklardan uzak ve yücedir"61 mealindeki âyetin Yahudilerden bir rahibin gelerek, "Sen kıyamet gününde Allah'ın; gökleri, yerleri, dağları, ağaçları, toprakları, suları ve bütün mevcudatı eline alıp silkeleyeceğini ve sonra da malik ve hâkim benim, nerede sultanlar, nerede krallar? diye sesleneceğini söylüyorsun" şeklindeki şaşkınlık tavrı üzerine Hz. Peygamber'in gülümseyerek bu haberi tasdik etmesi olayına istinaden nazil olduğunu kaydetmektedir. Burada konuyla ilgili başka âyet ve hadisleri de nakletmektedir. ${ }^{62}$ Bunun gibi Haşr sûresi 5. âyetin, askerî strateji sebebiyle ağaç kesme olayı konusunda kendilerine kısmî izin verilen müslümanları suçlayan müşrikler hakkında nazil olduğunu vurgulamaktadır. ${ }^{63}$ Aynı şekilde Sad sûresi'nde mücmel "ملأlmele" ifadesine veya âyetin nüzûlüne sebep olarak müşriklerin Ebû Tâlib'e gelip yeğeni Muhammed'i ikaz etmesini

\footnotetext{
57 Musannifek, Tefsîr, vr. B2b.

58 Musannifek, Tefsîr, vr. B59b.

59 Musannifek, Tefsîr, vr. A4a.

60 Musannifek, Tefsîr, vr. A209a-A209b-A210a-A210b.

61 ez-Zümer 39/67.

62 Musannifek, Tefsîr, vr. A36a.

63 Musannifek, Tefsîr, vr. A211a-A213a.
} 
istemelerinin anlatıldığı rivâyeti nakleder. Fakat rivâyetin kaynağıyla ilgili herhangi bir bilgi vermez. ${ }^{64}$

Musannifek; bazen de sûre ve âyetlerin, isimlerini verdiği bazı özel kişiler hakkında nazil olduğunu belirtmektedir. ${ }^{65}$ Örneğin, Müddessir sûresi 11 ve 25 . âyetler ile Asr sûresi'ndeki hakkı/dini anlatan ve sabrı tavsiye eden/sabreden kimse hariç mutlak olarak insanın ziyanda olduğunu belirten âyetin ${ }^{66}$ Velid b. Muğ̣̂re veya Kureyş kabilesinden bir genç, Mümtehine sûresi 1. âyetin Hâtıb İbn Ebî Beltea, Saff sûresi 2. âyetin de Abdullah b. Ravâha hakkında nazil olduğunu ifade etmektedir. ${ }^{67}$ Hakeza olay ve nedeni hakkında bilgi vermemekle birlikte Fussılet sûresi 40. âyetin de Ebû Cehil ve Ammâr b. Yâsir (öl. 37/657) hakkında nâzil olduğunu anlatmaktadır. ${ }^{68}$ Musannifek; âyetlerle olaylar arasındaki irtibata ve bu konudaki rivâyetlere de değinerek Cuma sûresi 11. âyetin Hz. Peygamber hutbe irâd ettiği sırada beraberindeki kervanla Şam'dan dönen ve O'nun on iki kişiyle yalnız kalmasına sebep olan Dihye b. Halîfe (öl. 50/670[?]) hakkında nâzil olduğunu kaydetmektedir. ${ }^{69}$

Kur'ân'ın bazı âyetlerinin, meydana gelen hadiseler veya sorulan sorular üzerine nazil olduğu bilinmektedir. Bu konuda Musannifek; âdetten kesilen, adet görmeyen veya hamile olan bayanların iddet süreleri ve talakları konusunda Hz. Peygamber'e sorulan sorular üzerine Talak sûresi 4. âyetin nâzil olduğunu belirtmektedir. ${ }^{70} \mathrm{~Hz}$. Peygamber ile bazı eşleri arasında geçen bir kısım üzücü olaylar üzerine Tahrîm sûresi'nin nâzil olduğunu belirtmesi de bu konuda bir başka örnektir. ${ }^{71}$

\subsection{Ahkâmü'l-Kur'ân}

Ahkâmü'l-Kur'ân; Kur'ân'ın ibadetler, muameleler ve cezalar gibi konulardaki hüküm içeren âyetlerini ele alan ilimdir. Kur'ân'da Bakara, Âl-i İmran, Nisâ ve Maide sûreleri gibi sarih ahkâm âyetleri muhtevi sûreler yanında, kendisinden istinbat yoluyla hüküm çıkarılabilen âyetler de bulunmaktadır. İmam-ı Şâfîi (öl. 204/820) gibi bazı İslam âlimleri Kur'an'ın ahkâm yönüne özel bir önem atfetmişlerdir. Tefsirlerinde bu konulara yer

64 Musannifek, Tefsîr, vr. A3a.

65 Musannifek, Tefsîr, vr. A64a-A317a-A374b.

66 Bk. el-Asr 103/2.

67 Musannifek, Tefsîr, vr. A286b-A370a-A217a-A224a.

68 Musannifek, Tefsîr, vr. A69a.

69 Musannifek, Tefsîr, vr. A232b.

70 Musannifek, Tefsîr, vr. A242b.

71 Musannifek, Tefsîr, vr. A246a. 
veren müfessirler olduğu gibi müstakil ahkâm tefsirleri de kaleme alınmıştır. ${ }^{72}$ Musannifek tefsirinde de Kur'an âyetlerindeki ahkâmın ele alındığı görülmektedir. Örneğin, Zümer sûresi 53. âyeti tefsirinde söz konusu hükmün şirke bulaşmamış bütün günahları kapsadığını ifade etmektedir. Bir sonraki âyette de Allah'ın günahkârlara tövbeyi emrederek bu genel ifadeyi kayıtladığını belirtmektedir.73 Mâ'ûn sûresi tefsirinde de Sa'd b. Ebî Vakkas'a (öl. 55/675), 'Namazdan gafil olanlar, onu terk edenler midir?' diye sorulması üzerine Sa'd'ın: ‘Hayır, onlar namaz vaktini geçirip de son anında kılanlardır. Şayet namazı terk etselerdi, terk etmeleri sebebiyle kâfir olurlardı' şeklindeki rivâyetini naklederek herhangi bir değerlendirmede bulunmaması, namazı terk edenlerle ilgili bir hükme de taraf olduğunu ima etmektedir. ${ }^{74}$

Bazı müfessirler Hz. Süleyman'ın, Yüce Allah'ı zikre mani olacak derecede atları sevdiği ve bu durumu fark edince onların ayak ve boyunlarını kestiği konusundaki görüşlerden söz etmektedirler. ${ }^{75}$ Musannifek de Sâd sûresi 33. âyeti bu yönde yorumlamakta, farklı görüşlere yer vererek bu konuda Ferrâ' dan (öl. 207/822) da delil getirmektedir. Bunları Allah'ın izni sonrasında kestiğini ve O'nun bazı şeyleri bir vakitte mubah kılıp, bir başka zamanda da yasaklayabileceğini belirtmektedir. ${ }^{76}$ Aynı şekilde Yüce Allah'ın; Hz. Nuh, İbrahim, Musa ve İsa gibi peygamberlere din kıldığı hükümleri Hz. Muhammed'e de şeriat kıldığını anlatan âyette Hz. Nuh'a tavsiye edilen yasak hükmünün bir kimsenin annesi, kardeşi ve kızıyla evlenmesinin yasaklanması olduğunu belirtmektedir. ${ }^{77}$

Ahkâmu'l-Kur'ân bağlamında Musannifek, Cuma namazıyla ilgili âyetteki “ذكر/Zikr"78 lafzından maksadın hutbe; "السعى/es-sa'y" in de hızlı yürümek, koşmak ve çalışmak manalarına geldiğini belirtmektedir. Aynı şekilde "وذروا البيع/alışverişi bırakın" ifadesinin sarih emir olduğunu; fakat ulemanın ihtilaf ettiğini, Cuma vaktinde satış yapmanın haramlığı konusunda seleften Mücâhit (öl. 103/721) ve Mâlik b. Enes (öl. 179/795)

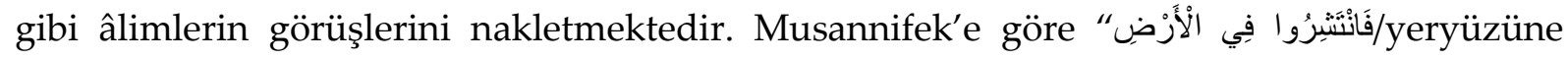
dağılın..." emri vücûb değil, ibâha ifade etmektedir. Hakeza ona göre " وَابْغَغُوا مِنْ فَضْنلِ

\footnotetext{
72 Zerkeşî, el-Burhân, 2/3-4.

73 Musannifek, Tefsîr, vr. A33b.

74 Musannifek, Tefsîr, vr. A373b.

75 Bk. et-Taberî, Ebû Ca'fer Muhammed b. Cerîr, el-Câmiu'l-beyân an te'vîli âyi'l-Kur'ân, (Dımeşk: Muessesetu'rRisâle, 1421/2001), 21/196; el-Mâverdî, Ebü'l-Hasen Ali b. Muhammed b. Habîb el-Basrî, Tefsîru'l-Kur'ân (enNüket ve'l-uyûn), (Beyrut: Dâru'l-Kütübi'l-'Ilmî, ts.), 5/93.

76 Musannifek, Tefsîr, vr. A9b.

77 Musannifek, Tefsîr, vr. A76a.

78 el-Cuma 62/10.
} 
السَّ/Allah'ın lütfundan nasip arayın" lafzı da tıpk1 "فَاصنطَادُو

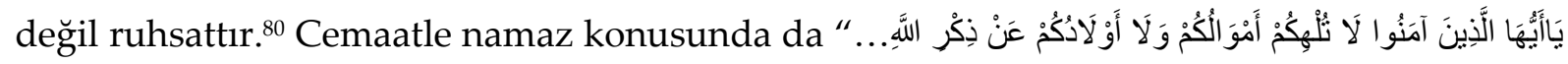
/Ey iman edenler! Mallarınız da çocuklarınız da sizi Allah'1 anmaktan alıkoymasın..."81 mealindeki âyetin, 'cemaatle namazdan alıkoymasın' şeklinde tefsir edildiğini belirtmektedir. ${ }^{82}$

Musannifek; hitabın hususi, hükmün umumi olması gibi Kur'ân'daki metodik bir ilkeye de değinmekte ve Kur'ân'da haber lafzında nehiylerin de bulunduğunu belirtmektedir. ${ }^{83}$ Buraya kadarki örneklerin; Musannifek'in Kur'ân'daki ahkâm âyetlerini beyan ettiğini, eserinin kapsam açısından müstakil bir ahkâm tefsiri olmasa bile onun Kur'ân'ın ahkâm âyetlerinin tefsiri konusundaki yaklaşımını ortaya koyduğunu ifade edebiliriz.

\subsection{Nâsih-Mensûh}

Nesih, sözlükte “izale etmek, kaldırmak, değiştirmek, nakletmek" anlamındadır. ${ }^{84}$ Neshin terim anlamı da bir ayetin hükmünün diğeriyle ortadan kaldırılmasıdır. ${ }^{85}$ Âyetleri tefsirinde nesh konusuna da değinen Musannifek; bir kısmını verdiğimiz, “.... لَنَا أَعْمَألنَا وَلَكُكْ

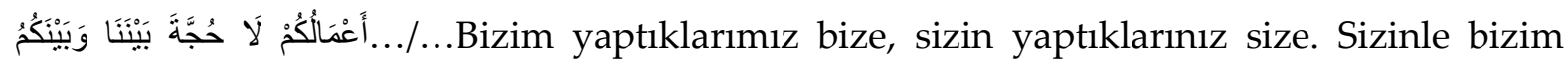
aramızda tartışmaya gerek yok..."86 mealindeki sorumluluğu, doğruluğu, tebliği, tahammülü ve sabrı emreden âyetin; kıtal/seyf âyeti ile neshedildiğini belirtmektedir. ${ }^{87}$ Söz konusu âyetin yorumunun da 'sizin deliliniz ile bizimki aynı düzeyde değildir. Bizimki derin ve kapsamlı sizinki ise tutarsız ve dayanaksızdır' şeklinde olduğunu kaydetmektedir. 88 Aynı şekilde konu bağlamında kendilerine fey' verilecek kimselerden söz eden Haşr sûresi 7. âyetin, ganimetlerden bahseden Enfâl sûresi'ndeki âyet ile nesholunduğunu ifade etmektedir. Çünkü zekât, malın zenginler arasında dönüp dolaşan bir meta olmasına engel

\footnotetext{
79 el-Mâide 5/2.

80 Musannifek, Tefsîr, vr. A231a-232b.

81 el-Münâfikûn 63/9.

82 Musannifek, Tefsîr, vr. A235b.

83 Musannifek, Tefsîr, vr. A240a-A243a.

84 Ebü'l-Fazl Cemâlüddîn Muhammed b. Mükerrem b. Alî b. Ahmed el-Ensârî er-Rüveyfiî, Lisânü'l- 'Arab, thk. Abdullah Ali el-Kebir v.dğr., (Kahire: Dâru'l-meârif, ts.), "nsh" md., 6/4407

85 Zerkeşî, el-Burhân, 2/29; Dihlevî, el-Fevzü'l-kebîr,57.

86 eş-Şûrâ 42/15.

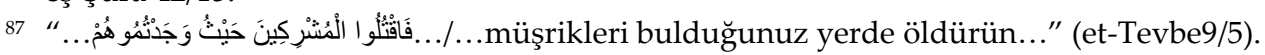

88 Musannifek, Tefsîr, vr. A77b.
} 
olmak üzere emredilmiştir. 'Allah Resûlü de zekât almaktan menolunmuştur' şeklinde konuyu izah etmektedir. ${ }^{89}$

Kimi kaynaklarda dini hükümlerdeki tedricîlik olarak belirtilen hususu Musannifek, nesh kavramıyla ifade etmektedir. Namazın öncelikle gece namazı olarak farz kılındığını, Hz. Peygamber ve ashabının ayakları şişene dek namaz kıldıklarını, fakat bir süre sonra bu durumun ikişer rekât halinde kılınan ve sonra da ziyadeleştirilen beş vakit namaz emriyle nesholunduğunu ifade etmektedir. ${ }^{90}$ Hakeza Müzzemmil sûresinin, inananları zorda bırakan ilk âyetlerinin sûrenin son âyetleri ile nesh edildiğini belirtmektedir.91

Musannifek'in tefsir nüshasında yer almadığı için nesih bağlamında tartışma konusu olan Bakara sûresi 106 ve Nahl sûresi 101. âyetler hakkındaki yorumlarını bilemiyoruz. Fakat buradaki örnekler sadedinde şunu ifade edebiliriz ki, Musannifek; Kur'ân'ın önceki şeriatleri neshetmesi yanında kendi içerisinde bazı hükümlerde de neshin mümkün olabileceğini düşünmektedir.

\subsection{Kısasü'l-Kur'ân}

Kısas; izini sürmek, takip etmek, hikâye etmek ve açıklamak anlamlarındaki kıssa/قصةٌ kelimesinin çoğuludur.92 Kısasü'l-Kur'ân; gaybî ve tarihi olaylar, durumlar ve haberler ile Kur'ân'ın nüzulü dönemindeki hadiselerden bahseden Kur'ân pasajlarını inceleyen ilimdir. ${ }^{93}$ Musannifek, Kur'ân'ın isimlerini zikrederken bunlardan birinin de "kasas" olduğunu belirtmektedir. Âl-i İmrân 62 ve Yûsuf sûresi 3. âyetlerde geçen "القصص/el-Kasas" kelimelerini buna delil olarak göstermektedir. Musannifek'in belirttiğine göre Kur'ân, önceki ve sonrakilerin haberlerini ihtiva etmektedir. Kur'ân'daki kıssaların maksadı da onların yolunu izlemek ve onlardan ibret almaktır. Kıssa lafzı, âyette bu anlamda kullanılmaktadır. ${ }^{94}$

Allah'ın hikmeti ve muradı gereği Kur'ân'da bazı âyetler mücmel olarak ifade edilmiştir. Özellikle kıssalarda gördüğümüz bu metotla zaman, mekân veya olayın kahramanı hakkında bilgi vermek ya da ayrıntıdan bahsetmek yerine âyet fehvasındaki ilgili mesaja vurgu yapılmaktadır. Buna rağmen farklı kültürlerle karşılaşılması veya merak duygusu insanları kıssalardaki mezkûr boşlukları doldurma çabasına sevk etmiştir. Bu

\footnotetext{
89 Musannifek, Tefsîr, vr. A212a.

90 Musannifek, Tefsîr, vr. A280b-A285a.

91 Musannifek, Tefsîr, vr. A284b.

92 Ebû Nasr İsmâîl b. Hammâd el-Cevherî, Tâcü'l-luga, thk. Abdülgafûr Attâr, (Beyrut: Dârü'l-'Ilm li'l-Melâyîn, 1407/1987), “kss" md., 3/1051.

93 Bk. Muhsin Demirci, Tefsir Terimleri Sözlüğ̈̈̈, (İstanbul: İFAV, 2017), 158.

94 Musannifek, Tefsîr, vr. B30a; el-Kasas 28/11.
} 
minvalde sahabe dönemi ve özellikle hicrî birinci asrın ikinci yarısından itibaren yani tâbiîn dönemiyle birlikte isrâiliyyât tabir edilen bilgilerin Kur'ân tefsirine girdiği görülmektedir. Ekseriyetle rivâyet tefsirlerinde karşılaşılan bu durumu Musannifek'te de kısmen görmek

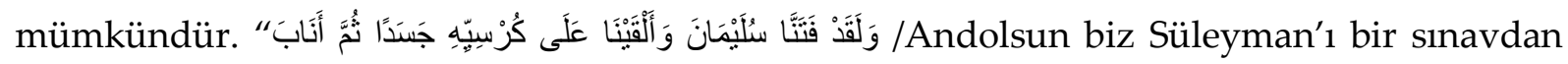
geçirmiş, tahtının üstüne bir ceset koymuştuk; sonra o bize yöneldi"95 mealindeki âyeti tefsirinde, S’alebî (öl. 427/1035), Mâverdî (öl. 450/1058) ve Kurtubî’de (öl. 671/1273) de anlatılan söz konusu cesedin kime ait olduğu, Hz. Süleyman'ın yüzüğünü alan cinnînin ismi, kaybolan yüzüğün bulunduğu mekân ve daha başka konularda sıhhati şüpheli bazı rivâyetler aktarılarak tefsir edilmektedir. Bu durum Musannifek'in Kur'ân'daki kıssalara yaklaşım tarzını da ortaya koymaktadır. ${ }^{96}$ Bir başka yerde de âyet metninde hâss bir isim

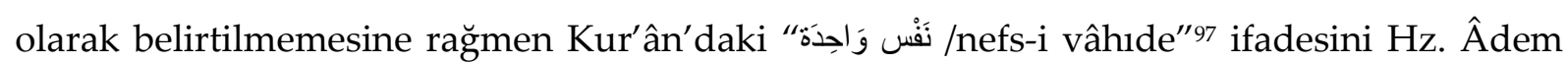
ve onun eşi Havva olarak izah etmiştir.98 Yeryüzü, sarsılmaz dağlar ve dünya üzerindekilerin muhtaç olduğu besinlerin yaratıldığı günlerin isimleri bağlamında Abdullah b. Selâm'ın (öl. 43/663-64) görüşünü nakletmektedir.99 Canlıların Cuma günü yaratıldığını, Hz. Âdem'in de Cuma gününün son anlarında var edildiğini ve kıyametin o günde gerçekleşeceğini belirtmektedir. ${ }^{100}$

Musannifek; Hz. Yunus'un kavmine azap inmek üzereyken onların, kendi içlerinde bulunan ilim sahibi bir kimseye müracaat etmeleri üzerine Hz. Yunus'un kızgınlıla

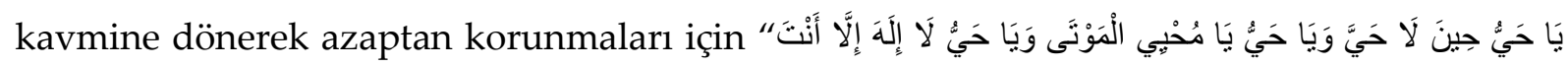
/Ey kendisinden başka hiçbir diri olmayan! Ey ölüleri dirilten diri, Ey kendisinden başka ilah olmayan diri" anlamındaki sözleri söylemelerini istediği ve neticede azabın kaldırıldığını anlatmaktadır. Taramalarımız neticesinde kıssayla ilgili aktarılan mezkûr sözlerin kaynağına ilişkin tefsir ve hadis literatüründe benzer aktarımlara ulaşılmıştır. ${ }^{101}$

95 Sâd 38/34.

96 Musannifek, Tefsîr, vr. A10a; Ayrica bk. Ebû İshâk Ahmed b. Muhammed b. İbrâhîm es-Sa'lebî en-Nîsâbûrî, elKeşf ve'l-beyân 'an tefsîri'l-Kur'ân, thk. Ebû Muhammed b. Âşûr, (Beyrut: Dâru İhyâi't-Türâsi'l-'Arabî, 1422/2002), 8/207; Ebû Abdillâh Muhammed b. Ahmed b. Ebî Bekr b. Ferh el-Kurtubî, el-Câmi' li-ahkâmi'lKur'ân, thk. Ahmed el-Berdûnî vd., (Kahire: Dâru'l-Kütübi'l-Misrî, 1383/1964), 15/202.

97 ez-Zümer 39/6.

98 Musannifek, Tefsîr, vr. A20b.

99 Musannifek, Tefsîr, vr. A60a.

${ }^{100}$ Musannifek, Tefsîr, vr. A61b.

${ }^{101}$ Musannifek, Tefsîr, vr. A75a. Rivâyetin kaynaklarıyla ilgili bk. Taberî, Câmiu'l-beyân, 15/210; Ebû Abdillâh Muhammed b. Ömer b. el-Hasan b. el-Huseyn er-Râzî, Mefâtîhu'l-gayb, (Beyrut: Dâru İhyâi't-Turâsi'l-Arabî, 1420/1999), 17/303. 


\subsection{Mekkî-Medenî}

Kur'ân âyet ve sûrelerinin bir kısmı Mekke, bir kısmı da Medine'de nâzil olmuştur. Ağırlıklı görüşe göre hicretten önce inenler Mekkî, hicretten sonra inenler de Medenî'dir. ${ }^{102}$ Diğer kutsal kitapların aksine defaten değil, peyderpey nazil olan Kur'ân'ın bu özelliğinin pek çok hikmeti bilinmekle birlikte onun doğru anlaşılması ve yorumlanmasına da etkisi inkâr edilemez. Musannifek, Müddessir sûresi'nin Kur'ân'ın ilk nâzil olan sûrelerinden biri olduğunu belirtmektedir. ${ }^{103}$ Bununla birlikte kendisi, sûre ve âyetleri tefsirinde onların Mekkî veya Medenî olduklarına işarette çoğunlukla hassas davranmış değildir. Hal böyleyken onun naklettiği sebeb-i nüzûl rivâyetlerinden sûre ve âyetlerin nüzûl yeri

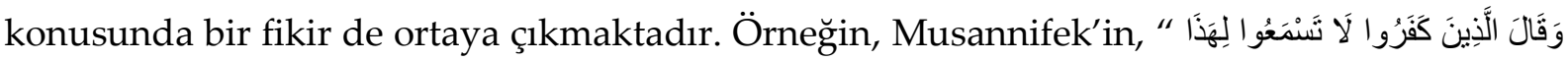

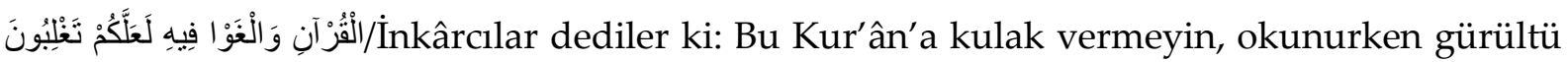
yapın, belki bastırırsınız"104 mealindeki âyette belirtilen sözün; Hz. Peygamber Kur'an okuduğunda ıslık çalıp el çırparak ona engel olmalarının istendiğini, bunun Ebû Cehil tarafından talep edildiğini belirtmesi âyetin Mekke'de nazil olduğunu göstermektedir. ${ }^{105}$ Aynı şekilde Kalem sûresi'nde; olur olmaz yere yemin eden, sürekli ayılayıp kusur arayan, laf taşıyan, kabalık, aşağılık, günahkârlık ve soysuzluk niteliklerinden sözü edilen kişinin Velid b. Muğîre olduğunu belirtmesi; mesaj, olay, kişiler ve mekân unsurları çerçevesinde meseleye bakıldığında mezkûr sûrenin Mekke döneminde nazil olduğu kanısında olduğunu göstermektedir. ${ }^{106}$

Musannifek'in sûre başlarında nüzûl yerlerini belirtmekte tesâhül gösterdiğini ifade etmiştik. Bununla birlikte tespit edebildiğimiz bir yerde Duhâ sûresi'nin Mekke'de nâzil olan üçüncü sûre olduğunu; burada ilk nâzil olan sûrenin Alâk, ikincisinin Kalem ve üçüncüsünün de Duhâ olduğunu ifade etmektedir. ${ }^{107}$

\subsection{Fezâilü'1-Kur'ân}

Kur'ân sûrelerinin değeri, üstünlügü ve özellikleri bağlamında Kur'ân'ın faziletleri hususu gerek tefsirlerde gerekse tefsir usûlü eserlerinde ulûmü'l-Kur'ân'ın temel başlıklarından biri olarak yer almaktadır. Öncelikle şu ifade edilmeli ki, “Allah’ın kelamı

\footnotetext{
102 Süyûtî, el-İtkân, 35.

${ }^{103}$ Musannifek, Tefsîr, vr. A285a.

104 el-Fussilet 41/26.

105 Musannifek, Tefsîr, vr. A65b.

${ }^{106}$ Bk. el-Kalem 68/10-16; Musannifek, Tefsîr, vr. A257b.

${ }^{107}$ Musannifek, Tefsîr, vr. A354b.
} 
olan Kur'an'ın diğer sözlere üstünlügü̈; O'nun, mahlûkata üstünlüğü gibidir." ${ }^{108}$ Bununla birlikte Kur'an'ın kendi içerisindeki faziletten söz edilecekse sûre ve âyetlerinin nüzûlü, hususiyetleri, muhtevası ve bunlara mahsus rivâyetler açısından meseleye yaklaşılmalıdır. ${ }^{109}$

Pek çok tefsir usûlü kaynağında görüldüğü üzere Musannifek de el-Kur'ân, el-Kitap, el-Furkân, en-Nûr, ez-Zikr, er-Rûh, eş-Şifa ve el-Mesânî gibi kimisi sıfat kimisi de müstakil olarak zikredilen Kur'ân isimleri ile bunların anlam ve iştikaklarına değinmektedir. ${ }^{110}$ Bakara sûresi'nin faziletiyle ilgili İbn Hıbbân'ın (öl. 354/965) Sahîh'inden şu rivayeti nakletmektedir:

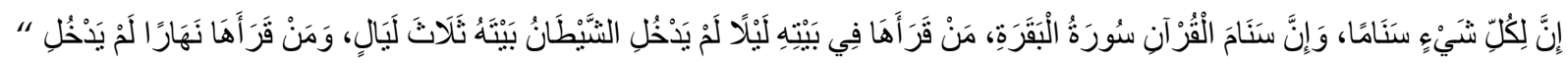

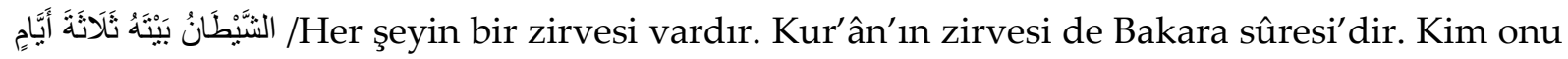
gece okursa üç gece şeytan onun evine giremez. Kim de onu gündüz okursa üç gün şeytan onun evine giremez."111 Aynı şekilde sûre hususiyetleri bağlamında Mâlik b. Enes'in (öl. 179/795) Muvatta'ından, ${ }^{112}$ Dârimî’nin (öl. 255/869) Sünen'inden, ${ }^{113}$ İbn Abdi'l-Berr'in (öl.463/1071) el-İstî‘ âb’ından ${ }^{114}$ bazı rivâyetleri aktardığı da görülmektedir.

Zümer sûresi'nin tefsirinde sûrenin fazileti ile ilgili olarak Vehb b Münebbih'ten (öl. 114/732) rivâyetle, “من أحب أن يعرف قضاء الله عز وجل في خلقه فليقرأ سورة الغرف/Allah'ın mahlûkat1 hakkındaki hüküm ve takdirini bilmek isteyen Ğuraf/Zümer sûresi'ni okusun" denildiğini nakletmektedir. ${ }^{115} \mathrm{~Hz}$. Peygamber'in gece namazlarına kalkıp da namaza başladığında Zümer sûresi 46. âyetini okuduğunu belirtmektedir. ${ }^{116}$

“الكثاني/el-mesânî"117 kelimesinin izahında mana bakımından iki vecih bulunduğunu ifade eden Musannifek, gerçekleri dile getirmek üzere Kur'ân'da kıssa, hüküm ve misallerin farklı yerlerde tekrarlandığını; va'd, va'îd, cennet, cehennem, dünya ve ahiretin zikri gibi konu ve kavramların birbiri ardınca eşleştirildiğini belirtmektedir. ${ }^{118}$ Psikolojik rahatsızlık, nazar ve kem gözlerden muhafaza için Kalem sûresi 51. âyetin okunabileceğini, ilgili âyetin bu nevi hastalıklardan da korunmadaki faziletini ifade etmektedir. ${ }^{119}$ Dolayısıyla bu ve

\footnotetext{
108 Bk. Zerkeşî, el-Burhân, 1/433.

109 Bk. Süyûtî, el-ìtkân, 784 .

${ }_{110}$ Musannifek, Tefsîr, vr. B27a-B34b.

${ }^{111}$ Musannifek, Tefsîr, vr. B3b; İbn Hibbân, Ebu Hâtim Muhammed b. Hibbân b. Ahmed el-Büstî, Sahîhu İbn Hibbân, thk. Şuayb el-Arnaût, (Beyrut, Muessesetü'r-Risâle, 1993/1414) “Kırâatü'1-Kur'ân”, 46.

112 Musannifek, Tefsîr, vr. B4a.

113 Musannifek, Tefsîr, vr. B3b.

${ }^{114}$ Musannifek, Tefsîr, vr. B4a.

115 Musannifek, Tefsîr, vr. A19a.

116 Musannifek, Tefsîr, vr. A32a.

117 ez-Zümer 39/23; el-Hicr 15/87.

118 Musannifek, Tefsîr, vr. A26a.

${ }^{119}$ Musannifek, Tefsîr, vr. A261b.
} 
benzeri rivâyetlerden hareketle konuyu değerlendiren Musannifek'in, fezâilü'l-Kur'ân ilkesini tefsirinde göz ardı etmediğini söylemek mümkündür.

\subsection{Hurûf-1 Mukattaa}

Kur'ân'da yirmi dokuz sûrenin başında kimi zaman müstakil bir âyet kimi zaman da içerisinde bulunduğu âyetin bir cüz'ü olarak mukattaa harfleri bulunmaktadır. Bunların yorumu ve durumu hakkında farklı görüssler mevcuttur. Musannifek de Bakara sûresi'ni tefsirinde Kûfe ve Basralıların bu konudaki görüşlerine ve "قلنّ/kulnâ" tabiriyle sûre ve âyetler hakkındaki bilginin "sem'â"ya dayandığını ve tevkifi olduğunu belirterek kendi görüşüne yer vermektedir. ${ }^{120}$ Usûl erbabının bunları birkaç mana çıkarılabilen müteşâbih lafızlardan saydıklarını, sahabe ve selefe göre hurûf-1 mukattaanın Allah'ın ilminden başkasının ihata edemeyeceği Kur'ânî bir sır olduğunu ve Âl-i İmrân sûresi 7. âyetteki vakf-1 lâzımın yerine göre iki görüşün ortaya çıktığını ifade etmektedir. ${ }^{121}$ Bunlardan ikinci görüşe göre ise düşünme ile ilgili âyetler, haber/hadis ve aklî deliller hurûf-1 mukattaayı anlamaya veya bunların anlamlandırılabileceğine delalet etmektedir. ${ }^{122}$ Ayrıca hurûf-1 mukattaa bağlamında "الم/elif lâm mîm" in sarf, nahiv, mantık ve meânî noktasında izahını yapan Musannifek mezkûr lafzın i'râbıyla ilgili muhtemel farklı görüşlere de değinmektedir. ${ }^{123}$ Musannifek'in belirttiğine göre İbn Abbâs'tan rivâyetle bir görüşe göre de "لم/elif lâm mîm" Allah'ın isimlerindendir. Yüce Allah, şanı ve değeri sebebiyle bununla kasemde

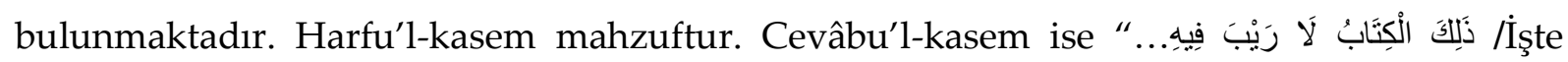
kitap; onda asla şüphe yoktur."124 mealindeki âyettir. Âl-i İmrân, Ankebût, Lokman, Rûm ve Secde sûresi gibi "لالم/elif lâm mîm" in geçtiği diğer sûrelerde de durum böyledir. ${ }^{125}$

Musannifek, hurûf-1 mukattaanın cümmel/ebced hesabı gibi harflerin sayılara delaleti ve ümmetlerin ecelleriyle ilgili rivâyetlere yer verir ki aynı rivâyetleri hem Râzi'de hem de diğer kaynaklarda görmek mümkündür. ${ }^{126}$ Musannifek, sûrelerin evvelinde geçen hurûf-1 mukattaalar konusunda farklı rivâyetlerin nakledildiğine işaret etmektedir. Kendisi de

\footnotetext{
${ }^{120}$ Musannifek, Tefsîr, vr. B5a.

${ }^{121}$ Musannifek, Tefsîr, vr. B6b; B7a.

${ }^{122}$ Musannifek, Tefsîr, vr. B9b; bu görüşle ilgili şu âyetlere yer vermektedir: el-Mâide 5/15; en-Nisâ 4/82-83; Muhammed 47/24; eş-Şuarâ 26/194-195.

${ }^{123}$ Musannifek, Tefsîr, vr. B6a-B18a-B18b-B19a-B20b.

124 el-Bakara 2/2.

125 Musannifek, Tefsîr, vr. B14a.

${ }^{126}$ Musannifek, Tefsîr, vr. B15a; Bk. Râzî, Mefâtîhu'l-gayb, 2/7-254; Şihâbüddîn Ahmed b. Muhammed b. Ömer elHafâcî, Hâşiyetü'ş-şihâb alâ tefsîri'l-Beyzâvî, (Beyrut: Dâru Sâdır, ts.), 1/171; Muhammed b. Abdulazîm, ezZürkânî, Menâhilü'l-'irfân fî̀ 'ulûmi'l-Kur'ân, (Beyrut: Dâru'l-Ma'rife, 1425/2005), 1/162-190-231.
} 
tefsirinde bunlara değinmeden geçmemektedir. Bu bağlamda Kalem sûresi'ndeki "ن/nûn" lafzı hakkında İbn Abbâs'ın; yazı yazılan "divit" dediğini, bazılarının da yeryüzünün, üzerinde bulunduğu bir "balık" olduğunu belirttiklerini anlatmaktadır. ${ }^{127}$

\subsection{Muhkem-Müteşâbih}

Muhkem, kendisinde kapalılık olmayan, manasına delaleti açıkça anlaşılabilen; müteşâbih ise benzerlik ve kapalılık gibi nedenlerle manasına delaleti açıkça anlaşılamayan âyetler için kullanılan bir terimdir. ${ }^{128}$ Âl-i İmrân sûresi'nde Kur'ân'ın muhkem ve müteşâbihâtının bulunduğu belirtilmektedir. ${ }^{129}$ Kur'ân'ın her âyeti anlaşılırlık bakımından eşit derecede değildir. Bazı âyetler başka bir delile ihtiyaç göstermeyecek derecede aklî bir delaletle anlaşılacak derecede açık ve anlaşılır iken bazı âyetler bu noktada başka birtakım delillerin bulunmasını gerektirmekte, başka benzer manalara da yorumlanabilmektedir. $\mathrm{Bu}$ yüzden Hz. Ali (öl. 40/661), Abdullah b. Abbâs'ı (öl.68/687) haricilerle tartışmaya gönderirken zûvücûh özelliğinden dolayı onlara Kur'ân'dan değil, sünnetten delil getirmesini istemiştir. ${ }^{130}$

Arş, kürsî ve istiva gibi konular müteşâbihâttandır. Musannifek, Sâd sûresi 34 . âyetteki Hz. Süleyman'ın taht1/yatağ1 ile ilgili Bakara sûresi'ndeki “الكرسي/el-kürsî” lafzına atıfta bulunarak müteşâbih olan bu kavramı bazı kelamcıların "ilim" olarak tevil ettiklerini ve bunu da "و "و لا يكرسئ علم الله انسان" şeklinde söylediklerini belirtmektedir. ${ }^{131}$ Zümer sûresi'nde

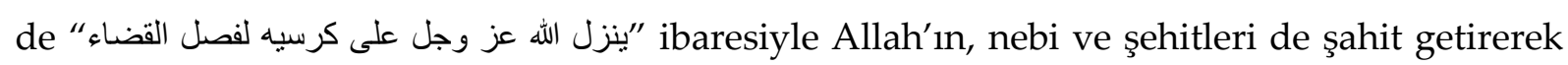
kitabı ve adalet terazilerini de ortaya koyacağı bir günde aralarında adaletle hükmedeceği esnada tahtından inmesinden söz etmektedir. ${ }^{132}$

Musannifek, Mü'min sûresi 7. âyeti tefsirinde ise arşı taşıyan melekler ve onların özellikleriyle ilgili bazı hadis kaynaklarında ve Taberî (öl. 310/922), Zemahşerî (öl. 538/1144), Râzî (öl. 606/1210) ve Âlûsî (öl. 1270/1854) gibi müfessirlerin tefsirlerinde detaylı bilgiler

\footnotetext{
127 Musannifek, Tefsîr, vr. A255b.

128 Subhî es-Sâlih, Mebâhis fî 'ulûmi'l-Kur'ân, (İstanbul: Dersaâdet, ts.), 282.

129 Âl-i İmrân 3/7.

${ }^{130}$ Musannifek, Tefsîr, vr. B45a-B45b.

${ }^{131}$ Musannifek, Tefsîr, vr. A9b.; “Kürsî” kelimesini diğer bazı müfessirler de "Allah'ın ilmi” şeklinde tefsir etmektedir. (Bk. M. Hamdi Yazır, Hak Dini Kur'ân Dili, (İstanbul: Azim Dağıtım, ts.), 2/161.

${ }^{132}$ Musannifek, Tefsîr, vr. A37a.
} 
veren rivâyetleri aktarmaktadır. ${ }^{133}$ Allah'ın ilk önce arşı yarattığını belirten rivâyeti naklederken onun mahiyeti ve oluşumu ile ilgili açıklamalara da değinmektedir. ${ }^{134}$

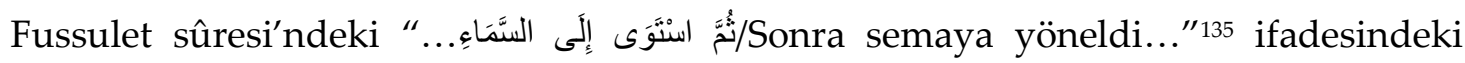
“istiva” tabirini, Allah'ın henüz duman halindeki göğü desteklemesi ve yükseltmesi şeklinde izah etmektedir. Bu bağlamda Allah'ın yeryüzünü yaratması sonrasında gökyüzünü yarattığını; rızıkların takdiri, dağların yerleştirilmesi, canlılar, nehir ve ağaçların yaratılmasının ise gökyüzünden sonra olduğunu belirtmektedir. ${ }^{136}$ Hâlbuki Kur'ân'ın diğer âyetlerinde gökyüzü ve yeryüzünün yaratılış önceliği farklı şekillerde geçmektedir. Çünkü söz konusu âyetlerde kronolojik sıralamadan ziyade sadece Allah'ın nimetleri siralanmak istenmektedir. ${ }^{137}$

\section{9. İ'câzü'l-Kur'ân}

İ'câz, âciz ve zayıf bırakmak demektir. ${ }^{138}$ Kur'ân terkibiyle birlikte kullanıldığında muhteva ve edebî özellikleri bakımından onun bir benzerinin meydana getirilemeyeceğini anlatan ilmi ifade etmektedir. İslam âlimleri Kur'ân'ın nazım, dil, üslup, lafız ve mana gibi belâgat ve i'câz yönlerini araştırmışlar, bu konuda üstün edebî eserler yazmışlardır. İlâhî bir kelam olması, naziresinin yapılamaması ve muhaliflerine meydan okuması Kur'ân'ın mu'cize olduğuna delalet etmektedir. ${ }^{139}$ Musannifek'e göre de i'câz, Kur'ân'ın bir özelliğidir. $\mathrm{Bu}$ konuda herhangi bir şüpheye de mahal yoktur. Buna işaret eden delillerden birisi de Hz.

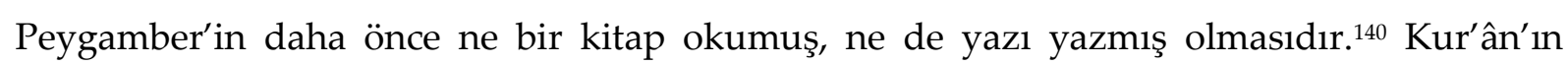
i'câzını, onun bir beşer sözü olmadığını, kuvvetli ve kudretli bir yaratıcının kelamı olduğunu gösteren bir başka delil ise sûre başlarındaki hurûf-1 mukattaalardır. ${ }^{141}$ Musannifek,

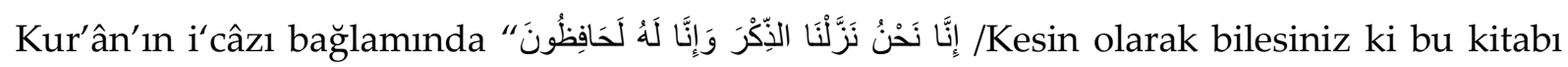

\footnotetext{
${ }^{133}$ Musannifek, Tefsîr, vr. A40a; Bk. Taberî, el-Câmiu'l-beyân, 21/354; Ebu'l-Kâsım Cârullah Mahmûd b. Ömer b. Muhammed ez-Zemahşerî, el-Keşşâf an hakâikt ğavâmidi't-tenzîl ve uyûni'l-ekâvîl fî̀ vucûhi't-te'vîl, (Beyrut: Dâru'lKitâbi'l-A'rabî, 1407/1986), 4/151; Râzî, Mefâtîhu'l-gayb, 27/487; Ebü's-Senâ Şihâbüddîn Mahmûd b. Abdillâh b. Mahmûd el-Hüseynî el-Âlûsî, Rûhu'l-me'ânî fì tefsîri'l-Kur'âni'l-Azîm ve's-seb'i'l-mesânî, (Beyrut: Dâru İhyâi'tTurâsi'l-A'rabî, ts.),12/299; 24/45.

${ }^{134}$ Musannifek, Tefsîr, vr. A61a.

${ }^{135}$ el-Fussilet 41/11.

${ }^{136}$ Musannifek, Tefsîr, vr. A60b-61a.

${ }^{137}$ Mevdûdî, Tefhîmü'l-Kur'ân, (İstanbul: İnsan, 1997), 7/31.

${ }^{138}$ Cevherî, Tâcü'l-luga, "acz" md., 3/883.

${ }^{139}$ Ebû Muhammed Abdülhak b. Gâlib b. Abdirrahmân el-Endelüsî, el-Muharrerü'l-vecîz fì tefsîri'l-kitâbi'l- 'azîz, thk. Abdüşşâfî Muhammed, (Beyrut: Dâru'l-Kütübi'l-'Ilmî, 1422/2001), 1/52.

${ }^{140}$ el-Ankebût 29/48.

${ }^{141}$ Musannifek, Tefsîr, vr. B13b-14a.
} 
kuşkusuz biz indirdik ve onu mutlaka koruyan da yine biziz."142 mealindeki âyeti zikrederken; şayet yeryüzünü su kaplasa, bütün mushaflar suya düşse bile Kur'ân'ın silinip yok edilemeyeceğini belirtmektedir. Bunun bir kinaye olduğuna da değinen müellif onu ezberleyen hafızların zihin ve gönüllerinde Kur'ân'ın daima korunacağını, eserinin yeryüzünden silinemeyeceğini, tebdil, tağyir ve tahrifin ona asla sirayet edemeyeceğini ifade

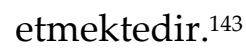

Kur'ân'ın edebî üslûbu, belâgat ve îcâzî özellikleri de onun i'câzını gösteren unsurlardandır. Tefsirinde Kur'ân'ın îcâzî yönlerine işaret eden Musannifek Bakara sûresi'ndeki “و مما رزقتاهم ينفقون......Kendilerine verdiklerimizden hayra harcarlar" mealindeki âyetteki "من/min" harf-i cerrinin teb'îydıyye olduğunu belirttikten sonra burada mef'ûlün fiilden önce gelmesinde tahsis ve kasr gibi bir nükte bulunduğunu anlatmaktadır. ${ }^{144}$ Yani sadece rızık olarak verilenlerden infak edilmeli, bunlar dışındakiler infak kapsamından çıkarılmalıdır. İnfak ise rızkın tamamından değil bir kısmından yapılmalı; Allah ve insanlar tarafından kınanmamak, itaba uğramamak için tedbirli olunmalı, israf edilmemelidir.

Kur'ân, belagât ve îcâzî özellikleriyle bütün edebî eserlerin zirvesindedir. Bu durumun göz ardı edildiği her türlü anlama yaklaşımı Kur'ân'ın gerçek manasını kavrama noktasında kısır ve yetersiz kalacaktır. Kur'ân'ın îcâzına işaret eden Musannifek bu bağlamda hazif, ihtisar, takdim-te'hîr, izmâr ve kinaye gibi me'ânî ve bedî ilmiyle ilgili edebî

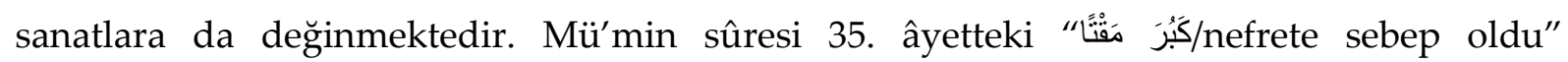
ifadesinde izmâr olduğunu, te'vîlinin de "كبر جدالهم و قولهم مقتالوك/tartışma ve sözleri nefrete sebep oldu" şeklinde olduğunu belirtmektedir. ${ }^{145}$

Bir karine ve delile istinaden, zikredilen kısmın maksadı anlatmaya yeterli olması sebebiyle sözün tamamı veya bir kısmının cümleden düşürülmesine hazif denilmektedir. ${ }^{146}$

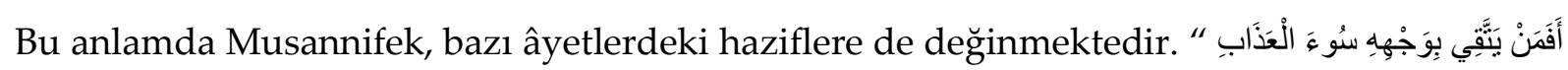
矢/Kryamet gününde o şiddetli azaba karşı kendini (çaresizlikten) yüzüyle korumaya çalışan kişi mi..."147 mealindeki âyette hazif bulunduğunu ve cevaben te'vîlinin de kıyasın tamamlayı1cı unsuru olması bakımından كمن يأتي امنا يوم القيامة/Kıyamet gününde güven içinde

\footnotetext{
142 el-Hicr 15/9.

${ }^{143}$ Musannifek, Tefsîr, vr. B23a.

${ }^{144}$ Musannifek, Tefsîr, vr. B53b.

${ }^{145}$ Musannifek, Tefsîr, vr. A56b; Ayrıca bk. A11a-A30a-A41a-A43a-A47a-A267a.

146 Zerkeşî, el-Burhân, 3/102.

147 ez-Zümer 39/24.
} 
gelen kişi gibi mi..." şeklinde olduğunu belirtmektedir. ${ }^{148}$ Kur'ân'ın pek çok yerinde cevabı mahzuf ifadelerin bulunduğunu belirten Musannifek, Tekasür sûresi'ndeki “ كَلَّ لَوْ نَعَلْكَونَ عِلْمَ الْيَقينِ /Hayır, keşke kesin bir bilgiyle bilmiş olsaydınız"149 mealindeki âyetin cevabının da 'Çoklukla övünmek sizi oyalamazdı' şeklinde hazfedildiğini belirtmektedir.150 Yine Fîl sûresi'ndeki “الم تر/görmedin mi?” ifadesinin Kur'ân'ın pek çok âyetinde olduğu gibi “العلم/el$1^{\prime} l \mathrm{~m}^{\prime \prime}$ den kinâye olduğunu belirtmektedir. ${ }^{151}$ Dolayısıyla bu ve benzeri örnekler i'câzü'lKur'ân konusunun Musannifek'in tefsirinde önem atfedilen ulûmü'l-Kur'ân maddelerinden biri olduğunu göstermektedir.

\subsection{Ahrufü's-Seb'a ve Kırâat-i A'şara}

Kur'ân'ın anlam zenginliği ve derinliğinin boyutlarından biri de kıraatlerdir. Yedi kıraatin dışındakileri şâz kabul eden Musannifek, tefsirinde zaman zaman kıraat farklılıklarına temas ederek bir kısım anlam inceliklerine işaret etmektedir. ${ }^{152}$ Bakara sûresi'ni tefsirinde "الم/elif lâm mîm" in okunuşu bağlamında, Fâtiha sûresi'ni tefsir ettiği birinci defterde kıraat-1 seb‘a'nın tevatüre bağlı olduğunu anlattığını belirtmektedir. ${ }^{153} \mathrm{Bu}$ bağlamda yer yer kıraatlere de değinen Musannifek, "İَşte kitap; onda asla şüphe yoktur. O, günahtan sakınanlar için bir rehberdir." mealindeki âyetteki kıraatleri şöyle sıralamaktadır:

a) Âyetteki "هُدَى /hüden" ifadesindeki “。/hâ" harfinin "g/vâv" s1z olarak dammeli okunması ki bu evlâ olan kıraat olup Zührî (öl. 124/742) ve ona tabi olanların kıraatidir.

b) İbn Kesîr'in (öl. 120/738) “فيهى/fîhî" şeklinde “//yâ" harfinin eklenip gösterilmesiyle okumasidir.

c) "فيهو/fîhû" şeklinde "g/vâv" harfi eklenip "o/hâ" harfini dammeli okumaktır.

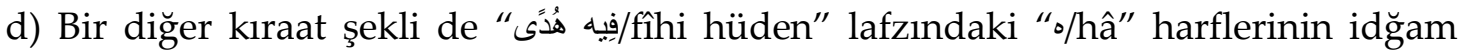

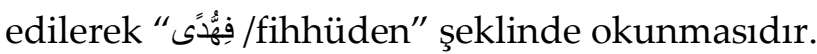

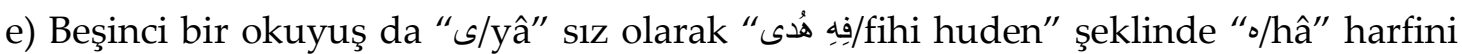
kesreli okumaktır. ${ }^{154}$

\footnotetext{
148 Musannifek, Tefsîr, vr. A26b.

149 et-Tekâsür 102/5.

${ }^{150}$ Musannifek, Tefsîr, vr. A369b.

${ }^{151}$ Musannifek, Tefsîr, vr. A371b.

152 Bk. Çelik, "Fatih Sultan Mehmet Han”, 1/153.

${ }^{153}$ Musannifek, Tefsîr, vr. B17a.

${ }^{154}$ Musannifek, Tefsîr, vr. B41a.
} 
Musannifek, Mü'min sûresi 19. âyeti tefsirinde Mekke kıraat imamlarından biri olarak meşhur olmasına rağmen yedi ve on kıraat ile ilgili kaynaklarda kıraati pek tercih edilmeyen İbn Muhaysın'ın (öl. 123/741) “خائنة/hâine”155 kelimesini “خيانة/hryâne” şeklinde okuduğu ile ilgili görüşüne yer vererek her hangi bir değerlendirmede de

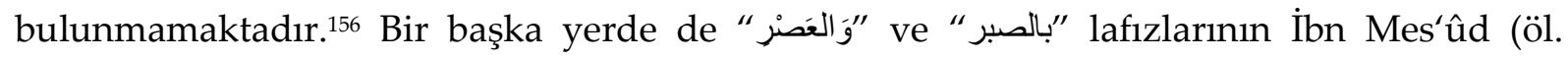

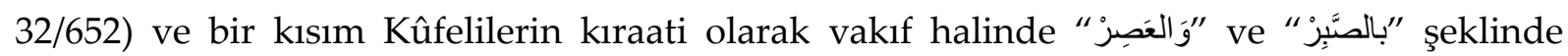

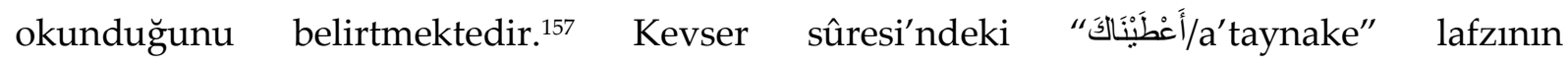
“أنَطْيَنَاكَكَ/entaynâke” şeklinde de okunduğunu söyler fakat okuyan kişi veya manaya etkisi konusunda hiçbir görüş belirtmez. ${ }^{158}$

Kur'ân'ın nüzûlü ve metinleşme sürecine atıfta bulunan Musannifek, Şûrâ sûresi 1 ve 2. âyetler bağlamında İbn Mes'ûd'un (öl. 32/652) şahsî mushafında söz konusu âyetlerin "ع/a'yn" harfinin hazfi ile "حمسق/hâ-mîm-sîn-kâf" biçiminde yazıldığını ve İbn Abbâs'ın (öl. 68/687) kırâatinin de bu şekilde olduğunu anlatmaktadır.159 Dil açısından en meşhur ve güzel okuyuş şekline işaret ederek mushaflardaki bazı kelimelerin harflerinin hazfedilmesiyle birlikte farklı kıraatlerin bulunduğunu da belirtmektedir. ${ }^{160}$ Cuma sûresi'ndeki “|فَاسَسْوَ/fes'a‘v"161 kelimesini Hz. Ömer (öl. 23/644), İbn Mes'ûd (öl. 32/652) ve başkalarının "فَامضو/femdû" şeklinde okuduklarını, hatta İbn Mes'ûd'un “|فَاسْعَوْو/fes'av" okunuşunu inkâr ettiğini ve 'şayet öyle okusaydım ridam düşene kadar koşardım' dediğini ifade etmektedir. ${ }^{162}$

Kıraatlerdeki anlam farklılıklarına değinen Musannifek, Âsım’dan (öl. 127 /745) bir

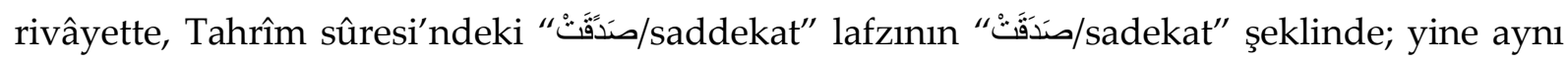

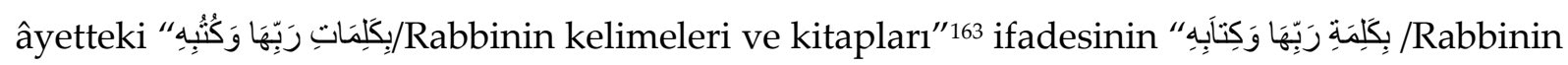
kelimesi ve kitabı" şeklinde de okunduğunu ifade etmektedir. Buna göre de kelime lafzından Hz. İsa'nın kul ve peygamberliği; kitap lafzından da İncil'in anlaşılmasının uygun olabileceğini; cemî'/çoğul okunduğu takdirde de Hz. Meryem tarafından İncil, Tevrat ve Zebur'un kabul edildiğinin anlaşılacağını belirtmektedir. ${ }^{164}$

\footnotetext{
155 el-Mü'min 40/19.

${ }^{156}$ Musannifek, Tefsîr, vr. A43b.

157 Musannifek, Tefsîr, vr. A369b.

158 Musannifek, Tefsîr, vr. A374b.

${ }^{159}$ Musannifek, Tefsîr, vr. A73b; İki sahabi arasındaki farklı kıraat anlayışına Haşr sûresi tefsirinde de değinmektedir. Bk. Musannifek, Tefsîr, vr. A212a.

${ }^{160}$ Musannifek, Tefsîr, vr. A82a.

161 el-Cuma 62/10.

162 Musannifek, Tefsîr, vr. A231b.

163 et-Tahrîm 66/12.

${ }^{164}$ Musannifek, Tefsîr, vr. A250b.
} 


\subsection{Vücûh ve Nezâir}

Kur'an'da geçen bir kelimenin farklı yerlerde kazandığı çeşitli manaları inceleyen bilim dalı ve bu dalda yazılan eserlerin ortak adına vücûh ve nezâir denilmektedir. ${ }^{165}$ Kur'ân tefsirinin kelime izahlarıyla başladığı düşünülmektedir. Bu anlamda hicrî ikinci asırdan itibaren Kur'ân'da geçen bu özellikteki kelimeleri inceleyen, vücûh ve nezâir konusuna özel önem veren eserlerin yazıldığı görülmektedir. İlahî muradın yüklendiği en küçük anlam öbekleri olan Kur'ân lafızlarının doğru anlaşılabilmesi için bu durumun göz önünde bulundurulması gerekmektedir. Vücûh, birden fazla manada kullanılabilen müşterek lafızdır. Bir başka ifadeyle yazılışı/hattı aynı lafzın farklı yerlerde muhtelif anlamlar ifade etmesidir. Nezâir ise aynı lafızlara sahip kelimelerin farklı yerlerde aynı anlamda

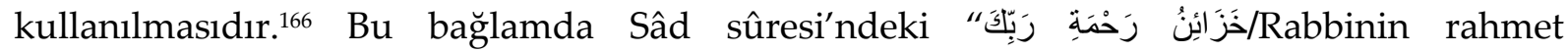
hazineleri"167 ifadesinde geçen "رحمة/rahmet" kelimesinin burada "رسالة/risâlet" anlaminda olduğunu belirten Musannifek, bu düşüncesini başka âyetlerle de desteklemektedir. ${ }^{168}$ Mü'min sûresi'nde ise kalp ve bedenlere canlılık veren "الروح/er-rûh" kelimesinin "الوحي/elvahy" anlamında olduğunu belirttikten sonra diğer âyetlerden örnekler vermektedir. ${ }^{169}$ Kur'ân'da farklı manalarda kullanılan kelimelerden biri de "vahy/وحى" dir. Bu duruma dikkat çeken Musannifek "اوحى/evhâ" fiilinin takdir etmek, düzenlemek ve emretmek anlaminda olduğunu belirtmektedir. ${ }^{170}$ Bu noktada Şûrâ sûresi'ni tefsirinde "الروح/er-rûh" kelimesinin vahy anlamına geldiğini; ruhların bedenler için can olduğu gibi kalbe hayat vermesinden ötürü kitabın da rûh olarak isimlendirildiğini kaydetmektedir. ${ }^{171}$

Genellikle tefsir usûlü eserlerinde nezâir kavramı bağlamında "النار/en-nâr", "الجحيم/elcehîm", "السقر/es-sakar" ve "الحطمة/el-hutame" lafızlarının cehennem anlaminda nezâir konusunun örnekleri olduğu belirtilmektedir. ${ }^{172}$ Musannifek de cehennemin altıncı kapısına; kıran, parçalayan ve öğüten manasında "الحطمة/el-hutame" isminin verildiğini; hatta çok yemek yiyerek adeta her şeyi ögüten insana da "الحطمة/el-hutame" denildiğini

\footnotetext{
${ }^{165}$ Farklı tanımlamalar için bk. Mustafa Karagöz, "Vücûh ve Nezâirin Terimleşme Süreci”, Bilimname, 14/1, (2008), 7-33.

166 Bk. Süyûtî, el-ìtkân, 346.

167 Sâd 38/9.

${ }^{168}$ Musannifek, Tefsîr, vr. A3b.

${ }^{169}$ Musannifek, Tefsîr, vr. A42b.

${ }^{170}$ Musannifek, Tefsîr, vr. A61b.

${ }^{171}$ Musannifek, Tefsîr, vr. A87a.

172 İsmail Cerrahoğlu, Tefsir Usûlü, (Ankara: TDV., 1997), 185; Demirci, Tefsir Usûlü, 146.
} 
belirtmektedir. ${ }^{173}$ Bir başka yerde de benzer örneklerinin Kur'ân'ın pek çok yerinde bulunabileceğini belirterek "يؤوس/yeûs" ve "فنوط/kanût" kelimelerinin lafız olarak birbirinden farklı; fakat anlam bakımından birbirinin aynı olduklarını kaydetmektedir. ${ }^{174}$

\subsection{Münâsebâtü'l-Âyât ve's-Suver}

Münâsebet; yakınlık, benzerlik ve uyumluluk anlamında bir kelimedir. Kur'ân'ın âyet ve sûreleri arasındaki mana, umum-husus, zıtlık-benzerlik ve sebep-sonuç gibi aklî ve hissî bazı konulardaki irtibata münâsebâtü'l-ây ve's-suver denilmektedir. ${ }^{175}$ Kur'ân'ın nüzûl sürecinin çeşitli zamanlarda ve birtakım sebeplere binaen tamamlanmış olması, onun kendi içerisindeki irtibat ve bütünlüğe dikkat edilmesini gerektirmektedir. Her ne kadar âyet ve sûrelere ayrılmış olsa da Kur'ân'ın kendine özgü hususiyetlerinden biri de söz konusu bölümler arasındaki münasebettir. Bu bağlamda Musannifek, Kureyş sûresi'ndeki “ îlâfi"176 lafzının başındaki "J/lâm" harfinin bir önceki sûre ile irtibatına delalet ettiğini ifade etmektedir. Ona göre buradaki "J/lâm" harfi, sözü öncesine bağlamak/sıla içindir. Yani, 'Ashâb-1 Kureyş'in yazın Yemen'e, kışın da Filistin'e yapmış oldukları kervan yolculuklarındaki güvenliklerini sağlamak için Allah, Ashâb-1 fil'e böyle yaptı. Onları Ashâb-1 fîl korkusundan korudu. O halde onlar Allah'a ibadet etsinler' denilmektedir. Belki de bu durumdan olsa gerek Hz. Ömer (öl. 23/644) akşam namazının ikinci rekâtında bu iki sûreyi birleştirerek okumuştur. ${ }^{177}$

Sûre ve âyetler arasındaki anlam ve üslup irtibatı tefsirlerde yer yer değinilen konulardandır. Musannifek, Asr sûresini tefsirinde bu sûrenin Tin sûresine benzediğini kaydetmektedir. ${ }^{178}$ Bir başka yerde de Fussılet sûresi 36. âyet ile İsrâ sûresi 53. âyet arasında lafız ve mana irtibatı bakımından karşılaştırmaya değer bir benzerlik olduğunu belirtmektedir. ${ }^{179}$ Aynı şekilde Musannifek'e göre Kıyâme sûresi'nin başındaki "У/lâ", sıla veya yeniden dirilmeyi inkâr edenlerin düşüncelerini red anlamina gelmektedir. Çünkü Kur'ân'ın bir kısmı diğer kısmıyla ittisal halindedir. ${ }^{180}$ Âyetlerdeki atıf ve edat gibi lafzî unsurlar ile anlam akışındaki aklî zorunluluklar bunun açık göstergelerindendir.

\footnotetext{
${ }^{173}$ Musannifek, Tefsîr, vr. A370b.

${ }^{174}$ Musannifek, Tefsîr, vr. A71b.

175 Bk. Süyûtî, el-ìtkân, 695.

176 el-Kureyş 106/1.

177 Musannifek, Tefsîr, vr. A372b.

178 Musannifek, Tefsîr, vr. A369b.

${ }_{179}$ Musannifek, Tefsîr, vr. A68a.

${ }^{180}$ Musannifek, Tefsîr, vr. A290a.
} 


\subsection{Mübhemâtü'1-Kur'ân}

Mübhem; anlam ve mahiyeti belirtilmeyen, kapalı ve gizli olan şey demektir. ${ }^{181}$ Mübhemâtü'l-Kur'ân ise ifade ve üslûba zenginlik katmak, meşhur ve malum olan faili beyana ihtiyaç duymamak, bir yerde açıklandığı için diğer yerde açılamaktan istiğna etmek gibi hikmet ve gerekçelerle Kur'ân'da varlıkların ism-i işâret, ism-i mevsûl ve zamirlerle ifade edildiği yerleri araştırma konusu edinen ilimdir. ${ }^{182}$ Kur'ân'ın bu hususiyetteki âyetlerine de değinen Musannifek; Fussılet sûresi 29. âyette inkâr edenleri saptırdığ1 anlatılan ve ism-i mevsulle(الََّيَنِ) işaret edilen cin ve insandan maksadın iblis ile Âdemoğlu Kâbil olduğunu ifade etmektedir. ${ }^{183}$ Aynı şekilde 33. âyetteki "من/men" ism-i mevsûlü ile anlatılan Allah'a çağıran kişinin; peygamber, âlim veya hayra davet eden her kişiye şamil olduğunu beyan etmektedir. Burada kastedilenin müezzinler olduğunu belirten Hz. Aişe (öl. 58/678) rivâyetini de nakletmektedir. ${ }^{184}$

Bir kısmı ismi, bir kısmı da sıfatı olmak üzere Kur'ân; Furkân, Kitâb ve Zikir gibi farklı lafızlarla kendinden bahsetmektedir. ${ }^{185}$ Bununla ilgili olarak Musannifek, Teğâbün sûresi 7. âyette ism-i mevsûl ile Kur'ân' dan söz edildiğine, onun bir isminin de "النور/en-Nûr" olduğuna işaret etmektedir. ${ }^{186}$

\section{Sonuç}

Yüce Allah tarafından insanlara gönderilen Kur'ân, azim ve kerim bir kitaptır. Kur'ân, nâzil olduğu dönemden itibaren tekrar tekrar okunan; lafzı, manası, dili ve belâgat özellikleri gibi yönleriyle sürekli araştırılan bir kaynaktır. İlmî, nazarî ve fiilî noktalarda Kur'ân'a gösterilen azami hassasiyet neticesinde insanların ve çağların özellikleriyle paralel olarak farklı Kur'ân anlayış ve yorumları ortaya konmuştur. Bu minvalde kimi zaman özel gayretler, kimi zaman da komisyon veya idari tasarruflarla yürütülen faaliyetler sonucunda muhtelif eserler kaleme alınmıştır. Osmanlı dönemi müfessirlerinden Alâüddîn Alî b. Muhammed b. Mes'ûd el-Bistâmî eş-Şâhrûdî(Musannifek) (öl. 875/1470) de böyle bir gayret içerisine girerek elimizdeki nüshalar üzerinden değerlendirmeye çalıştığımız mezkûr tefsirini kaleme almıştır.

\footnotetext{
${ }^{181}$ Cevherî, Tâcü'l-luga, “bhm” md., 5/1875.

182 Süyûtî, el-ìtkân, 765-783.

${ }^{183}$ Musannifek, Tefsîr, vr. A66a.

${ }^{184}$ Musannifek, Tefsîr, vr. A67a-b.

185 Bk. Taberî, Câmiu'l-beyân, 1/94; Süyûtî, el-i̇tkân, 135.

${ }^{186}$ Musannifek, Tefsîr, vr. A237b.
} 
Erken yaşlarda eser yazmaya başlayan Musannifek; hızlı yazma yeteneği, muhakeme gücü, ilmî derinliği, birikimi, meseleleri ele alış biçimi ve gayretiyle şerh, telif ve derleme türlerinde eserler yazmıştır. Aldığı eğitim, dönemin yazın kültürü ve siyasi idarenin etkisiyle eserlerini Arapça ve Farsça kaleme almıştır. Bu durumun yansımalarını tefsirinde de görmek mümkündür. Tefsirinde hem dirayet hem de rivâyet yönteminin izlerini görebildiğimiz Musannifek, belâgat konuları ve edebî izahlarıyla da oldukça dikkat çekicidir. Tefsirinde sade bir dil kullanmakta, tekrarlar ve sözü uzatacak gereksiz izahlardan da kaçınmaktadır. et-Tefsîr ve'l-müfessirûn gibi yakın dönem meşhur tabakat kitaplarında isminden bahsedilmemiş olsa da Katip Çelebi, Tâşköprîzâde ve Bursalı Mehmed Tahir'in eserlerinde Musannifek'ten söz ettikleri görülmektedir.

$\mathrm{Bu}$ araştırmamızda her biri ayrı bir bilimsel çalışma konusu olan ulûmü'l-Kur'an maddelerini detaylıca değerlendirmekten ziyade bunlarla ilgili olarak Musannifek'in Kur'ân'1 tefsir metodu ve yaklaşımındaki tespitlerimizden örnekler verilmeye çalışılmaktadır. Araştırmamızın başından itibaren ifade edilen bütün bu bilgiler bize Musannifek'in Kur'ân tefsirindeki yetkinliğini, yazmış olduğu tefsirin zamanın şartları içerisinde ulûmü'l-Kur'ân ve tefsir usûlü açısından üstün konumunu göstermektedir. Ulûmü'l-Kur'ân maddeleri elbette buradakilerden ibaret değildir. Fakat burada Musannifek hakkında yeterli kanaat oluşturacağı düşünülerek makale sınırları çerçevesinde sayıları farklılık arz eden pek çok ulûmü'l-Kur'ân konusundan sadece bir kısmına yer verilmektedir. Tamamına yakınını dikkatle okumaya çalıştığımız Musannifek'e ait yazma tefsir nüshaları; konusu, muhtevası ve üslûbu bakımından ilmî araştırmaya değer niteliktedir. Farsça ve Arapça olarak kaleme alınan ilgili tefsir nüshasında Kur'ân'ın yetmiş beş sûresi ve Bakara sûresinin beş âyetinin tefsirine yer verilmektedir. Bir tefsir eseri olması sebebiyle her ne kadar Esbâbu'n-nüzûl, Vücûh ve Nezâir, Fezâilü'l-Kur'ân, Mekkî-Medenî, Kisasü'l-Kur'ân, Hurûf-1 mukattaa ve İ'câzü'l-Kur'ân gibi Kur'ân ilimleri ve usûl konuları hususi başlıklar altında ele alınmamış olsa da söz konusu maddelere yapılan atıfların âyetleri tefsirde önemli rol oynadı̆̆ı anlaşılmaktadır.

Araştırmalarımıza dayanarak sonuçta şunu ifade edebiliriz ki, eserlerinden de anlaşılacağı üzere Musannifek velût bir şahsiyettir. Mezkûr ana ve alt başlıklar noktasında Musannifek; kaynak, üslup ve yöntem bakımından klasik tefsir geleneğini devam ettirmiş, Kur'ân'1 anlama ve yorumlamakta ulûmü'l-Kur'ân ve tefsir usûlünün temel konularını tefsirine uygulamıştır. 


\section{Kaynakça}

Âlûsî, Ebü's-Senâ Şihâbüddîn Mahmûd b. Abdillâh b. Mahmûd el-Hüseynî. Rûhu'l-me'ân̂̂ fî tefsîri'l-Kur'âni'l-Azîm ve's-seb'ı'l-mesânî. Beyrut: Dâru İhyâi't-Turâsi'l-A'rabî. ts.

Bangi İsmail. Farsça Dilbilgisi. Ankara: A.Ü. İlahiyat Fakültesi Yayınları, 1390/1971.

Başkan, Yahya. "Siyasi Mekân Değişikliğinin Eser Telifine Yansımasına Bir Örnek: Musannifek". Doğu Araştırmaları. 10/1 (Ocak 2012), 117-122.

Bedeva, Abdullah. Alâuddin Ali b. Muhammed el-Bistâmî Musannifek'in Kaside-i Bürde Şerhi'nin Tahkiki. İstanbul: Marmara Üniversitesi, Sosyal Bilimler Enstitüsü, Yüksek Lisans Tezi, 2012.

Begavî, Ebû Muhammed Hüseyin b. Mes'ûd. Meâ'limu't-tenzîl fî̀ tefsîri'l-Kur'ân. thk. Abdurrezzâk el-Mehdî. Beyrut: Dâru İhyâi't-Turâsi'l-Arabî, 1420/1999.

Bilmen, Ömer Nasuhi. Büyük Tefsir Tarihi/Tabakâtü'l-Müfessirîn. İstanbul: Ravza Yayınları, 2008.

Buhârî, Ebû Abdillâh Muhammed b. İsmâil b. İbrâhîm, el-Cu'fî. el-Câmu's-sahîh, thk. Muhammed Züheyr b. Nâsır. b.y.: Dâru Tavkı'n-Necât, 1422/2001.

Tâhir, Bursalı Mehmed. Osmanlı Müellifleri. İstanbul: Matbaa-i Âmire. 1333/1914.

Cerrahoğlu, İsmail. Tefsir Usûlü, 11. Baskı, Ankara: TDV Yayınları, 1997.

Cevherî, Ebû Nasr İsmâîl b. Hammâd. Tâcü'l-luga, thk. Abdülgafûr Attâr. Beyrut: Dârü'l-'Ilm li'l-Melâyîn, 1407/1987.

Çelik, Ersin. “Fatih Sultan Mehmet Han'ın Emriyle Yazılan Farsça Tefsir”. Osmanlı Döneminde Tefsir. ed. Hidayet Aydar v.dğr., 131-160. İstanbul: Ensar Neşriyat, 2018.

Demir, Ziya. Osmanlı Müfessirleri. İstanbul: Ensar Neşriyat, 2006.

Demirci, Muhsin. Tefsir Usûlü. 65. Basım, İstanbul: İFAV, 2018.

Demirci, Muhsin. Tefsir Terimleri Sözlü̆ğü. İstanbul: İFAV, 2017.

Dihlevî, Ebû Abdilazîz Kutbüddîn Şah Veliyyullâh. el-Fevzü'l-kebîr fî usûli't-tefsîr. Dimeşk: Dâru'l-ğavsânî, 1427/2007.

Endelüsî, Ebû Muhammed Abdülhak b. Gâlib b. Abdirrahmân b. Gâlib el-Muhâribî elGirnâtî. el-Muharrerü'l-vecîz fî̀ tefsîri'l-kitâbi'l-'azîz, thk. A. Abdüşşâfî Muhammed. Beyrut: Dâru'l-Kütübi'l-'Ilmî, 1422/2001.

Hanbelî, Ebü'l-Ferec Abdü'l-Hayy b. I'mâd. Şezerâtü'z-zeheb fi ehbâri men zeheb. thk. Abdülkadir el-Arnâût. Beyrut: Dâru İbn Kesîr, 1413/1993.

Hafâcî, Şihâbüddîn Ahmed b. Muhammed b. Ömer. Hâşiyetü'ş-şihâb alâ tefsîri'l-Beyzâvî. Beyrut: Dâru Sâdır, ts.

İbn Hibbân, Ebu Hâtim Muhammed b. Hibbân b. Ahmed el-Büstî. Sahîhu İbn Hıbbân, thk. Şuayb el-Arnaût, Beyrut:Muessesetü'r-Risâle, 1414/1993.

İbn Manzûr, Ebü'l-Fazl Cemâlüddîn Muhammed b. Mükerrem b. Alî b. Ahmed el-Ensârî erRüveyfiî. Lisânü'l- 'Arab, thk. Abdullah Ali el-Kebir v.dğr., Kahire: Dâru'l-meârif, ts.

Karagöz, Mustafa. “Vücûh ve Nezâirin Terimleşme Süreci”. Bilimname. 14/1, (2008), 733.

Karaver, Ümit. “Şeyh Ali el-Bistâmî”nin (Musannifek) Biyografisi ve Tefsir Alanındaki Çalışmaları". Osmanlı'da İlm-i Tefsir. ed. Harun Abacı vd 69-109. İstanbul: İsar, 2019.

Kâtib Çelebi, Hacı Halîfe Mustafa b. Abdillah. Keşfü'z-zunûn 'an esâmi'l-kütüb ve'l-fünûn. Beyrut: Dâru İhyâi't-Turâsi'l-Arabî, ts.

Kurtubî, Ebû Abdillâh Muhammed b. Ahmed b. Ebî Bekr b. Ferh. el-Câmi' li-ahkâmi'l-Kur'ân, thk. Ahmed el-Berdûnî vd. Kahire: Dâru'l-Kütübi'l-Misrî, 1383/1964.

Mâverdî, Ebü'l-Hasen Ali b. Muhammed b. Habîb el-Basrî. Tefsîru'l-Kur'ân(en-Nüket ve'luŷ̂n). Beyrut: Dâru'l-Kütübi'l-'Ilmî, ts.

Mevdûdî. Tefhîmü'l-Kur'ân. İstanbul: İnsan Yayınları, 1417/1997. 
Öztürk, Mustafa. “Osmanlı Tefsir Kültürüne Panoramik Bir Bakış”. Osmanlı Toplumunda Kur'ân Kültürü ve Tefsir Çalışmaları I. ed. Bilal Gökkır v.dğr., İstanbul: İlim Yayma Vakfi, 2011.

Râzî, Ebû Abdillâh Muhammed b. Ömer b. el-Hasan b. el-Huseyn. Mefâtîhu'l-gayb. Beyrut: Dâru İhyâi't-Turâsi'l-Arabî, 1420/1999.

Sa'lebî, Ebû İshâk Ahmed b. Muhammed b. İbrâhîm en-Nîsâbûrî. el-Keşf ve'l-beyân 'an tefsîri'lKur'ân, thk. Ebû Muhammed b. Âşûr. Beyrut: Dâru ihyâi't-türâsi'l-arabî, 1422/2002.

Salih, Subhî. Mebâhis fî ulûmi'l-Kur'ân. İstanbul: Dersaâdet, ts.

Süyûtî, Ebü'l-Fazl Celâlüddîn Abdurrahman b. Ebî Bekr b. Muhammed el-Hudayrî. el-i̇tkân fî̀ u'lûmi'l-Kur'ân. thk. Fevvâz Ahmed Zemerlî. Beyrut: Dâru'l-Kitâbi'l-Arabî, 1427/2007.

Şâhrûdî (Musannifek), Alâüddin Alî b. Muhammed b. Mes'ûd el-Bistâmî. Tefsîru Musannifek. Konya İl Halk Kütüphanesi, 3759: 1a-403b. Konya Yazma Eser Kütüphanesi.

Şâhrûdî (Musannifek), Alâüddin Alî b. Muhammed b. Mes'ûd el-Bistâmî. Tefsru Musannifek, Veliyyuddîn Efendi, 169: 1a-86b. Beyazıt Yazma Eser Kütüphanesi.

Taberî, Ebû Ca'fer Muhammed b. Cerîr b. Yezîd b. Kesîr b. Gâlib el-Âmulî. el-Câmiu'l-beyân an te'vîli âyi'l-Kur'ân. thk. Ahmet Muhammet Şakir. Dimeşk: Muessesetu'r-Risâle, $1421 / 2001$.

Taşdelen, Sinan. Musannifek Alaaddin Ali Bin Muhammed'in Mevlânâ'nın Mesnevî́si ile İlgili Risâlesi. Konya: Selçuk Üniversitesi, Sosyal Bilimler Enstitüsü, Doktora Tezi, 2007.

Tâşköprîzâde, Ahmed Efendi. Miftâhu's-sa'âde ve misbâhu's-siyâde fì mevzûu'âti'l-'ulûm. Beyrut: Dâru'l-Kütubi'l-'Ilmî, 1405/1985.

Tâşköprîzâde, Ahmed Efendi. eş-Şekâiku'n-Nu'mânî fì 'Ulemâi'd-Devleti'l-'Osmânî. Beyrut: Daru'l-Kitabi'l-Arabî, ts.

Yaşaroğlu, M. Kâmil. "Musannifek". Türkiye Diyanet Vakfi İslam Ansiklopedisi. 31/239-240. İstanbul: TDV Yayınları, 2006.

Yazır, M. Hamdi. Hak Dini Kur'ân Dili. İstanbul: Azim Dağıtım, ts.

Zehebî, Muhammed Huseyn. et-Tefsîr ve'l-Müfessirûn. Kâhire: Mektebetü Vehbe, ts.

Zemahşerî, Ebu'l-Kâsım Cârullah Mahmûd b. Ömer b. Muhammed. el-Keşşâff an hakâikı ğavâmidi't-tenzîl ve uyûni'l-ekâvîl fì vucûhi't-te'vîl. Beyrut: Dâru'l-Kitâbi'l-A'rabî, 1407/1986.

Zerkeşî, Ebû Abdillâh Bedrüddîn Muhammed b. Bahâdır b. Abdillâh et-Türkî el-Mısrî elMinhâcî. el-Burhân fî u'lûmi'l-Kur'ân. thk. Ebu'l-Fadl İbrahîm. Beyrut: Dâru İhyâi'lKütübi'l-A'rabî, 1376/1957.

Ziriklî, Hayruddîn b. Mahmûd. el-A'lâm. 15. Baskı, Beyrut: Dârü'l-'Ilm li'l-Melâyîn, $1422 / 2002$.

Zürkânî, Muhammed b. Abdulazîm. Menâhilü'l-'irfân fì 'ulûmi'l-Kur'ân. Beyrut: Dâru'lMa'rife, 1425/2005. 